\title{
Burial and thermal history of the Intra-Sudetic Basin (SW Poland) constrained by 1-D maturity modelling - implications for coalification and natural gas generation
}

\author{
DARIUSZ BOTOR
}

\begin{abstract}
Kinetic maturity modelling was performed using publicly available vitrinite reflectance data, for nine well sections in the Intra-Sudetic Basin (NE part of the Bohemian Massif) in order to reconstruct its burial and thermal history. The modelling results indicate that the Carboniferous strata reached maximum palaeotemperatures of $c .100-260{ }^{\circ} \mathrm{C}$ in the latest Carboniferous to early Permian. The Carboniferous-Permian magmatic activity must have contributed to high heat flow (c. 90-150 mW/m² during the late Palaeozoic), adding to the effect of sedimentary burial (to a total depth c. $3-6 \mathrm{~km}$ in the early Permian), and caused the coalification of organic matter (c. $0.6-4.5 \%$ of vitrinite reflectance), and finally natural gas generation. Major hydrocarbon products were dominated by methane. The second phase of temperature rise occurred due to mainly Late Cretaceous sedimentary burial, but it had no effect on the maturation of the Carboniferous organic matter. - Key words: Variscides, Bohemian Massif, Carboniferous, maturity modelling, coalification, vitrinite reflectance.
\end{abstract}

Botor, D. 2020. Burial and thermal history of the Intra-Sudetic Basin (SW Poland) constrained by 1-D maturity modelling - implications for coalification and natural gas generation. Bulletin of Geosciences 95(4), 497-514 (11 figures, 1 table). Czech Geological Survey, Prague. ISSN 1214-1119. Manuscript received January 30, 2020; accepted in revised form July 28, 2020; published online October 18, 2020; issued November 15, 2020.

Dariusz Botor, AGH University of Science and Technology, Faculty of Geology, Geophysics and Environmental Protection, al. Mickiewicza 30, Kraków30-059, Poland; botor@agh.edu.pl

The processes of coalification in coal-bearing basins are mainly determined by the thermal evolution of the basin, which is usually directly related to its burial history. The thermal maturity pattern of the organic matter (degree of coalification, coal rank) is therefore directly related to the burial history of the stratigraphic section analyzed, and the heat transport through the rocks (e.g. Hantschel \& Kauerauf 2009).

The Intra-Sudetic Basin (ISB) is well-known for its bituminous and anthracite coal deposits occurring in deep, strongly faulted synclines (Kwiecińska 1967; Lipiarski 1976; Mastalerz \& Jones 1988; Bossowski 1995; Kwiecińska \& Nowak 1997; Nowak 1993, 1996, 1997, 2000; Uglik \& Nowak 2015; Pešek \& Sivek 2016). Coal was mined in two districts in Poland, Wałbrzych and Nowa Ruda, and in one in the Czech Republic (Žaclér district). Mining operations began in the nineteenth century and the coal mines were all closed by 1999 , although there is some potential for further coal and anthracite exploitation. The complicated geological setting (e.g. faults, the steep dips of the upper Carboniferous coal-bearing strata, magmatic events), the abundance of gases (mainly methane and carbon dioxide) and related hazards of methane explosions or gas and rock outbursts, however, make traditional underground coal production uneconomic (Kotarba \& Rice 2001; Sechman et al. 2013, 2017).

The ISB is a relatively rare case of basin in which a particularly high thermal regime resulting from magmatic processes governed a coalification processes. The thermal history and coalification processes of the ISB have, however, seldom been studied (Kułakowski 1979, Mastalerz \& Jones 1988, Botor et al. 2020). One of the major products of coalification is methane, and although the coalbed methane reserves in the ISB have not yet been estimated precisely, it might be worthy of exploitation. The distribution and migration of these gases is related to the thermal history of the ISB, and therefore our new findings also contribute to a deeper understanding of this relationship, which might allow for a better prediction of natural gases within sedimentary sequence. The main aim of this study is therefore to improve understanding of the thermal conditions which caused coalification processes in the ISB. This paper is based solely on the kinetic maturity modelling of vitrinite reflectance data which is adopted from previous papers (Chruściel et al. 1985; Bossowski 1997, 2001; Nowak 2000; Ihnatowicz 2001; Botor et al. 2020). The maturity modelling takes into account recent lowtemperature thermochronology results (Sobczyk et al. 

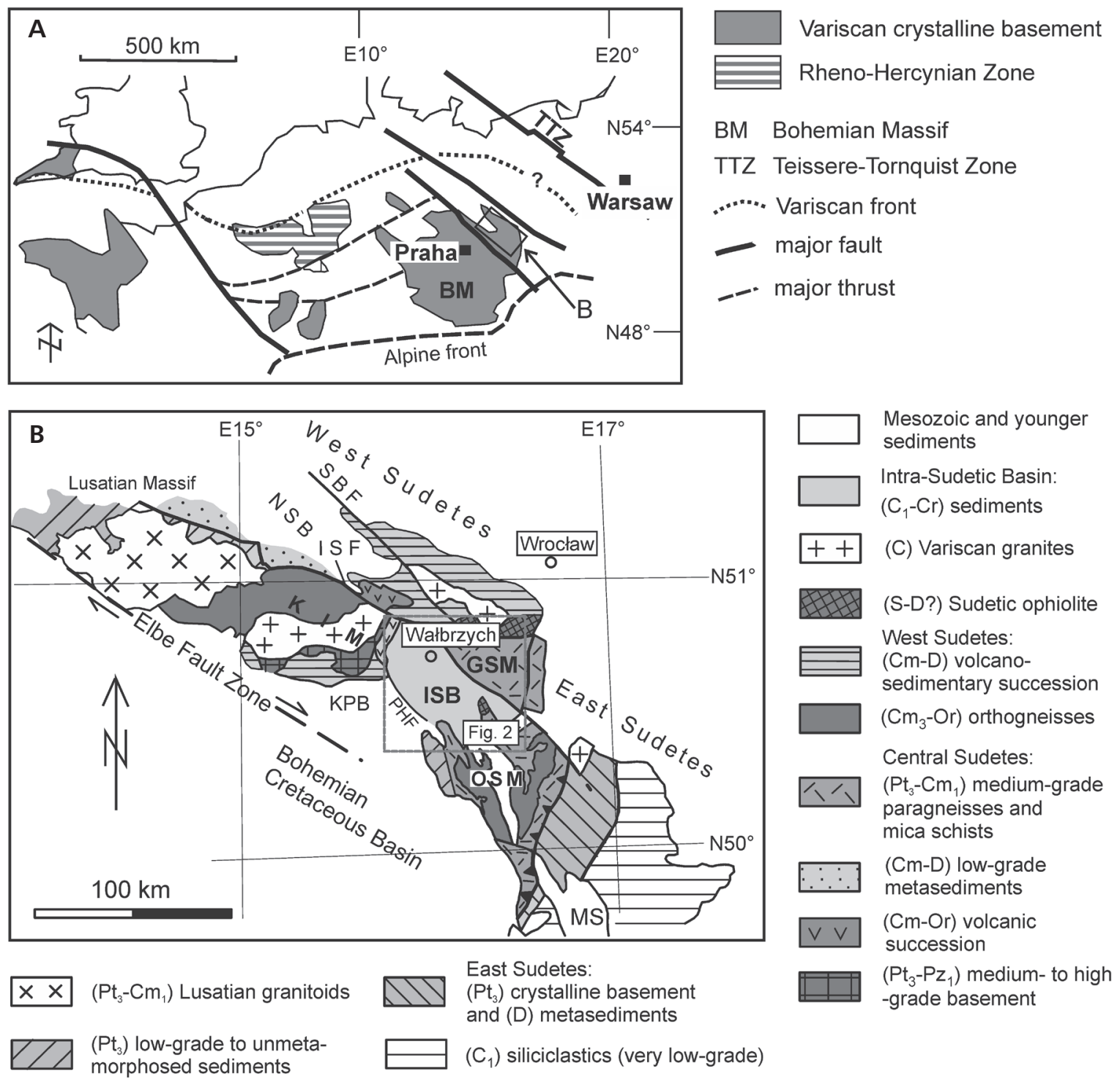

Figure 1. A - location of the Intra-Sudetic Basin within the Variscan belt of Europe. $\bullet$ B - geological sketch of the NE part of the Bohemian Massif (Sudetes Mts.). Abbreviations: ISB - Intra-Sudetic Basin; NSB - North-Sudetic Basin; GSM - Góry Sowie Massif; ISF - Intra-Sudetic Fault; KIM - Karkonosze-Izera Massif; KPB - Krkonoše Piedmont Basin; MS - Moravo-Silesian Zone; OSM - Orlica-Śnieżnik Massif; PHF - PoříćíHronov Fault. Age assignments: Pt3 - late Proterozoic; Cm - Cambrian; Or - Ordovician; S - Silurian; Pz1 - Lower Palaeozoic; D - Devonian; C - Carboniferous; Cr - Cretaceous (modified after Mazur et al. 2006, 2012; Botor et al. 2019).

2015, 2020; Botor et al. 2019) and Raman spectroscopy data (Botor et al. 2020). Combining several lines of evidence in a more comprehensive interpretation enabled an improved maturity modelling.

\section{Geological setting}

The ISB is one of the largest intramontane troughs of the Variscides in central Europe (Figs 1 and 2; e.g. Awdankiewicz 2004, Mazur et al. 2006, Opluštil \& Cleal 2007, Ziegler \& Dèzes 2007). The ISB includes a large depression that is bounded by faults (Fig. 2). The total thickness of the sedimentary sequences reaches $c .12 \mathrm{~km}$. The ISB is surrounded by both crystalline basement units of the Variscan consolidation age and by Palaeozoic sedimentary basins (Figs 1, 2).

The ISB originated as an intramontane depression with fluvial sequences, mainly conglomerates and sedimentary breccias of the middle to upper Viséan (Teisseyre 1968, 1975; Awdankiewicz et al. 2003; Turnau et al. 2005; Fig. 3). The upper Carboniferous continental succession, c. $2000 \mathrm{~m}$ thick, consists of predominantly coal-bearing sediments which are succeeded by red beds (Fig. 3; Nemec et al. 1982, 
Dziedzic \& Teisseyre 1990, Bossowski \& Ihnatowicz 2006). In the Polish part of the ISB, the coal-bearing strata are divided into the following formations (Fig. 3): Wałbrzych, Biały Kamień and Žaclér (of which the lower part is called the Boguszów Member and the upper part the Gorce Member). These strata include $c .80$ coal seams (Bossowski \& Ihnatowicz 2006). The lower Permian (Autunian) sediments comprise continental clastic deposits (Dziedzic \& Teisseyre 1990; Fig. 3). In the Saxonian (early Permian), tectonic inversion led to a significant exhumation of the ISB, particularly its elevated margins (Dziedzic \& Teisseyre 1990, Awdankiewicz 2004).

In post-Variscan times, the Carboniferous to lower Permian strata were covered by the latest Permian-Early Triassic continental strata and Upper Cretaceous shallow marine deposits (Figs 2, 3) (Lorenz \& Mroczkowski 1978, Skoček \& Valečka 1983, Uličný et al. 2009). No sediments of the Middle Triassic to Early Cretaceous age are known because the Bohemian Massif existed as an emerged, tectonically inactive landmass, subject to slow erosion and intense weathering, as evidenced by planation surfaces below the Late Cretaceous sediments and occurrences of thick kaolinic weathering mantles on the Palaeozoic basement rocks (e.g. Migoń \& Lidmar-Bergström 2001,
Ziegler \& Dèzes 2007, Danišík et al. 2012). The presentday relict of the Late Cretaceous sedimentary record spans Cenomanian through Coniacian in the ISB, although in adjacent parts of the Bohemian Cretaceous Basin (e.g. the North-Sudetic Basin) the preservation extends to the Santonian (Skoček \& Valečka 1983, Wojewoda 1997, Milewicz 1997, Uličný et al. 2009). In the ISB and adjacent areas, the present-day thickness of Cretaceous sediments ranges from $350 \mathrm{~m}$ in Batorów Syncline to $1200 \mathrm{~m}$ in Nysa Graben (Wojewoda 1997, McCann 2008). In the latest Cretaceous to Palaeocene, the Bohemian Massif was affected by transpressional deformation (Kley \& Voigt 2008), that caused a reactivation of Variscan faults (Scheck et al. 2002), exhumation of elevated blocks and inversion of the Cretaceous basins (Skoček \& Valečka 1983; Aramowicz et al. 2006; Kley \& Voigt, 2008; Ventura et al. 2009; Danišík et al. 2010, 2012; Sobczyk et al. 2015, 2020; Botor et al. 2019). Later, the Sudetes were intensively eroded, and a peneplain was developed (Migoń \& LidmarBergström 2001). Cenozoic basaltic volcanism developed in the Sudetes in many localities, but outside the ISB area (e.g. Birkenmajer et al. 2004). Neogene uplift of the Bohemian Massif can be attributed to lithospheric buckling and transpressional reactivation of crustal discontinuities
Figure 2. Geological sketch map of the Intra-Sudetic Basin with analyzed borehole locations (based on various sources including Sawicki 1995, Awdankiewicz et al. 2003, Bossowski \& Ihnatowicz 2006, Botor et al. 2019). Abbreviations: PHF - Poříčí-Hronov Fault; SF - Struga Fault.

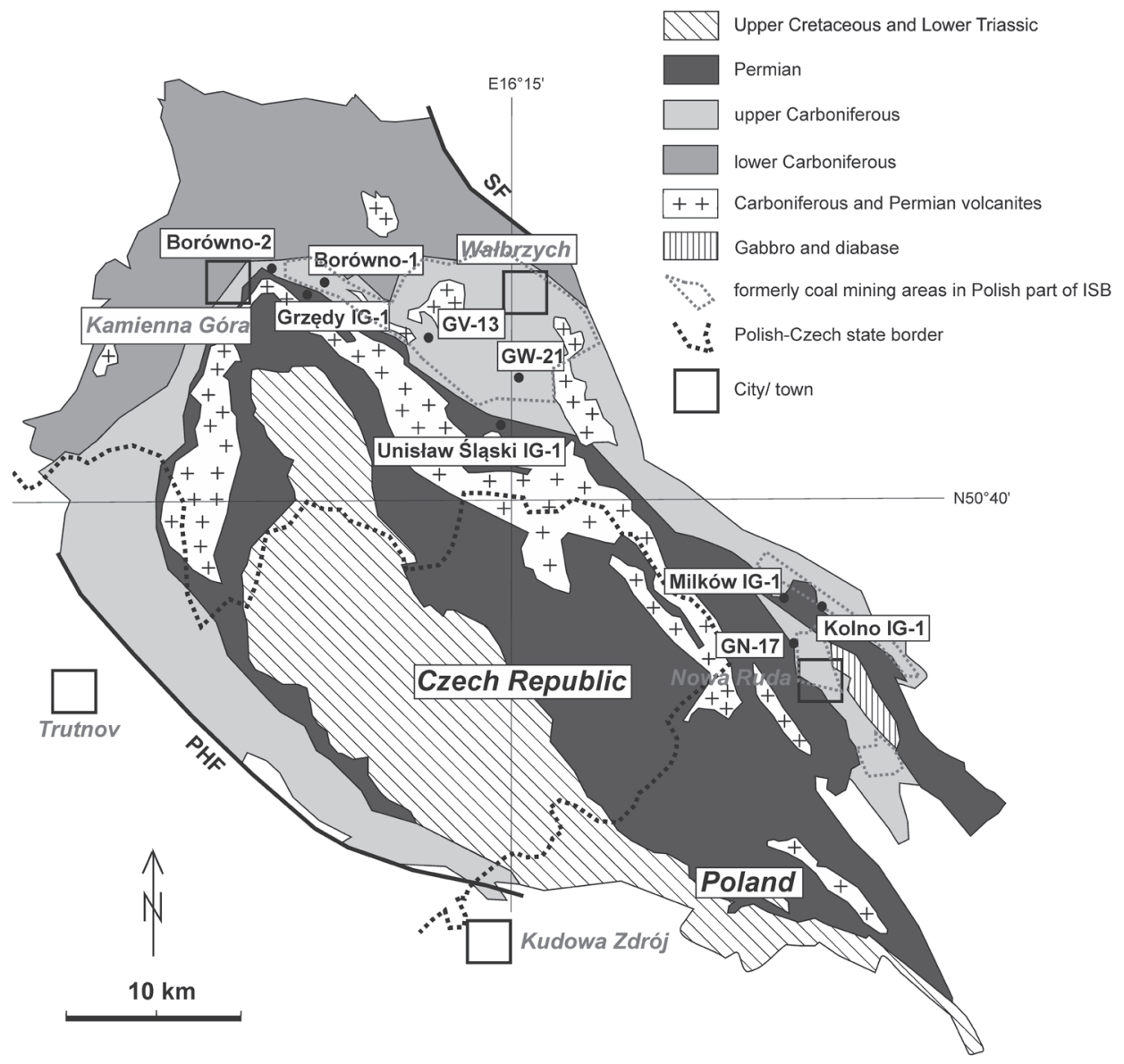




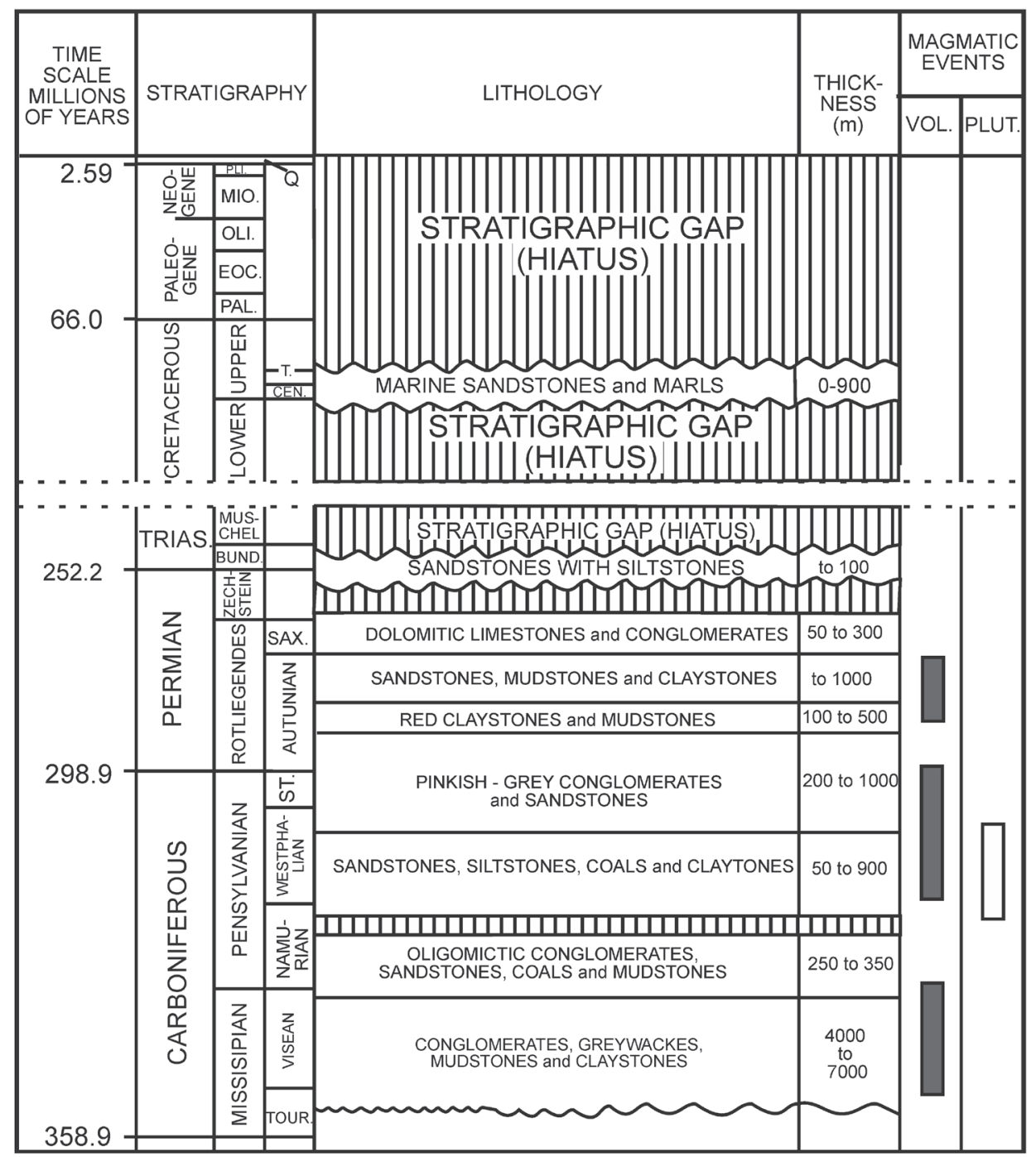

Figure 3. Simplified lithostratigraphy of the Intra-Sudetic Basin (modified after Dziedzic \& Teisseyre 1990, Bossowski et al. 1995, Bossowski \& Ihnatowicz 2006, Botor et al. 2019). Abbreviations: Bund. - Bundsandstein; Muschel. - Muschelkalk; Pal. - Palaeocene; Eoc. - Eocene; Oli. - Oligocene; Mio. - Miocene; Pli. - Pliocene; Tour. - Tournaisian; St. - Stephanian; Sax. - Saxonian; Cen. - Cenomanian; T. Turonian; VOL. - volcanic rocks; PLU. - plutonic rocks.
(Ziegler \& Dèzes 2007). The Late Palaeozoic evolution of the ISB was associated with several stages of magmatic/ volcanic processes during the middle Viséan, late Carboniferous, and early Permian, the latter corresponding to a maximum of volcanic activity (Awdankiewicz 2004, Ulrych et al. 2004, Opluštil et al. 2016). This magmatism included widespread volcanic complexes and shallowlevel intrusions, interstratified in Carboniferous-Permian sedimentary successions (Awdankiewicz 2004, Mazur et al. 2006).

The geothermal gradient reached up to $60^{\circ} \mathrm{C} / \mathrm{km}$ in the Variscides of Central Europe (Teichmüller \& Teichmüller 1986), however, the high heating caused by Variscan intrusions could increase this value to $80-100{ }^{\circ} \mathrm{C} / \mathrm{km}$ in the ISB (Kułakowski 1979, Mastalerz \& Jones 1988, Botor et al. 2020) or locally even to $c .200{ }^{\circ} \mathrm{C} / \mathrm{km}$ in northern part of the Czech Republic (Suchý et al. 2019). Such high geothermal gradients would give heat flow values as high as c. $100-180 \mathrm{~mW} / \mathrm{m}^{2}$ (e.g. Allen \& Allen 1990). Recent values of the geothermal gradient for the ISB vary between 22 and $25^{\circ} \mathrm{C} / \mathrm{km}$ (Bruszewska 2000).

The upper Carboniferous coal-bearing sequence of the ISB includes coals ranging from high-volatile bituminous to anthracitic (Bossowski 1995; Kwiecińska 1967; Lipiarski 1976; Mastalerz \& Jones 1988; Nowak 1993, 1996, 1997, 2000; Bossowski \& Ihnatowicz 2006; Uglik \& Nowak 2015). The lowest values of mean random vitrinite reflectance (VR) are recorded close to basin margins $(c .0 .6 \% \mathrm{VR})$, while the highest ones are found in the central parts (over $4.5 \% \mathrm{R}_{\max }$ ). VR gradients are variable (usually in the range $0.2-0.3 \% \mathrm{VR}$ per $100 \mathrm{~m}$ ), but locally reaching $0.6 \% \mathrm{VR}$ per $100 \mathrm{~m}$ in the centre of the basin (Chruściel et al. 1985, Mastalerz \& Jones 1988, Nowak 2000). According to Mastalerz \& Jones (1988) the most intense coalification presumably took place during the Westphalian A-B, due to sedimentary burial.

Recent low-temperature thermochronology results suggest that the Bohemian Massif was affected by Meso- 
zoic re-heating caused by burial and/or increased heat flow, Late Cretaceous inversion-related exhumation and some Cenozoic rifting (Thomson \& Zeh 2000; Glasmacher et al. 2002; Ventura \& Lisker 2003; Filip \& Suchý 2004; Aramowicz et al. 2006; Ventura et al. 2009; Danišík et al. 2012; Vamvaka et al. 2014; Wolff et al. 2015; Sobczyk et al. 2015, 2020; Botor et al. 2017, 2019). Significant sedimentary burial may have caused a resetting of zircon helium ages in the central part of the Sudetes during the Late Cretaceous (Danišík et al. 2012, Sobczyk et al. 2015). In the ISB, Cenomanian to Turonian sedimentary burial has been recently documented using thermochronology data (Botor et al. 2019).

\section{Methods}

Vitrinite is the organic maceral group most often used for reflectance measurements due to its relatively progressive change in optical properties with increasing maximum temperature. The vitrinite reflectance determination method is now widely applied in order to establish the thermal maturity of coal and dispersed organic matter (kerogen) in fine-grained rocks (e.g. Suarez-Ruiz et al. 2012, Ferreiro Mählmann \& Le Bayon 2016). The increase in VR value is dependent on many parameters, including temperature, geologic time, pore fluid pressure, fluid chemistry, and the advancement of tectonic deformation (e.g. Barker \& Pawlewicz 1994, Huang 1996, Dalla Torre et al. 1997, Suchý et al. 1997, Le Bayon et al. 2011), but the effect of maximum temperature and duration of heating are the most important (Teichmüller 1987, Mukhopadhyay 1992). The relationship between VR, temperature, and heating time can be used for thermal history reconstruction by applying chemical reaction kinetics using Arrhenius equations (Lopatin 1971; Sweeney \& Burnham 1990; Waples et al. 1992a, b; Hantschel \& Kauerauf 2009). A number of kinetic models of vitrinite maturation have been proposed, as reviewed by Waples (1980), Sweeney \& Burnham (1990), Morrow \& Issler (1993), Burnham et al. (2017) and Nielsen et al. (2017).

In this work, integrated numerical modelling in selected borehole sections was used to reconstruct the burial and thermal history of the ISB and thus to derive the history of coalification and natural gas generation. Computer maturity modelling was carried out using the 1-D (one-dimensional) PetroMod ver.11 software (Schlumberger). Vitrinite reflectance evolution was modelled applying the Sweeney \& Burnham (1990) algorithm $\left(\right.$ EASY $\% \mathrm{R}_{\mathrm{o}}$ ). The validity of the burial and thermal history models was verified through a comparison of measured (Chruściel et al. 1985; Bossowski 1996, 1997, 2001; Nowak 2000; Ihnatowicz 2001; Botor et al. 2020) and calculated VR values, as well as present-day corrected borehole temperature data (Bossowski 1996, 1997, 2001; Bruszewska 2000; Ihnatowicz 2001). The stratigraphic, lithologic and present-day temperature data were taken from Bossowski (1996, 1997, 2001), Ihnatowicz (2001) and Bossowski \& Ihnatowicz (2006).

Modelling procedure involves establishing a conceptual model (Waples et al. 1992a, b) based on the lithostratigraphy of the analyzed well that is used as

Table 1. Conceptual model applied to the Miłków IG-1 well. Abbreviations: Fm. - Formation; Mb. - Member. In lithology types the following system was applied for abbreviations: SANDcongl (first lithology in upper case and second in lower case) - $70 \%$ sandstone and $30 \%$ of conglomerate; SAND\&SHALE (both lithologies in upper case) - $50 \%$ sandstone and $50 \%$ shale.

\begin{tabular}{|c|c|c|c|c|c|c|c|c|c|}
\hline \multirow{3}{*}{ Unit/event } & \multicolumn{4}{|c|}{ (metres) } & \multicolumn{4}{|c|}{$(\mathrm{Ma})$} & \multirow{3}{*}{ lithology } \\
\hline & \multirow{2}{*}{ top } & \multirow{2}{*}{ bottom } & \multirow{2}{*}{ thickness } & \multirow{2}{*}{ exhumed } & \multicolumn{2}{|c|}{ deposition } & \multicolumn{2}{|c|}{ exhumation } & \\
\hline & & & & & from & to & from & to & \\
\hline Quaternary & 0 & 1 & 1 & & 2 & 0 & & & SILTSTONE \\
\hline exhumed Late Cretaceous & 0 & 0 & 0 & 3000 & 98 & 82 & 82 & 2 & SANDcalc. \\
\hline exhumed Lower Triassic & 0 & 0 & 0 & 100 & 252 & 250 & 250 & 98 & Sandstone \\
\hline exhumed Permian & 0 & 0 & 0 & 1800 & 298 & 290 & 290 & 252 & SANDcongl \\
\hline Krajnów Fm. (Autunian) & 1 & 118 & 117 & & 299 & 298 & & & SANDcongl \\
\hline Ludwikowice Mb. (Stephanian C) & 118 & 320 & 202 & & 302 & 299 & & & SANDcongl \\
\hline Łomnica Mb. (Stephanian A-B) & 320 & 474 & 154 & & 311 & 302 & & & Conglomerate \\
\hline Petrovice-Grzmiaca Mb. (Westphalian D) & 474 & 572 & 98 & & 312 & 311 & & & SANDcongl \\
\hline Gorce Mb. (Westphalian B-C) & 572 & 718 & 146 & & 315 & 312 & & & SILT\&SAND \\
\hline Boguszów Mb. (Westphalian A-B) & 718 & 874 & 156 & & 317 & 315 & & & SILTsandy \\
\hline Biały Kamien Mb. (Namurian C-Westphalian A) & 874 & 896 & 22 & & 318 & 317 & & & Conglomerate \\
\hline Wałbrzych Fm. (Namurian A-B) & 896 & 1151 & 255 & & 327 & 318 & & & SILT\&SAND \\
\hline
\end{tabular}



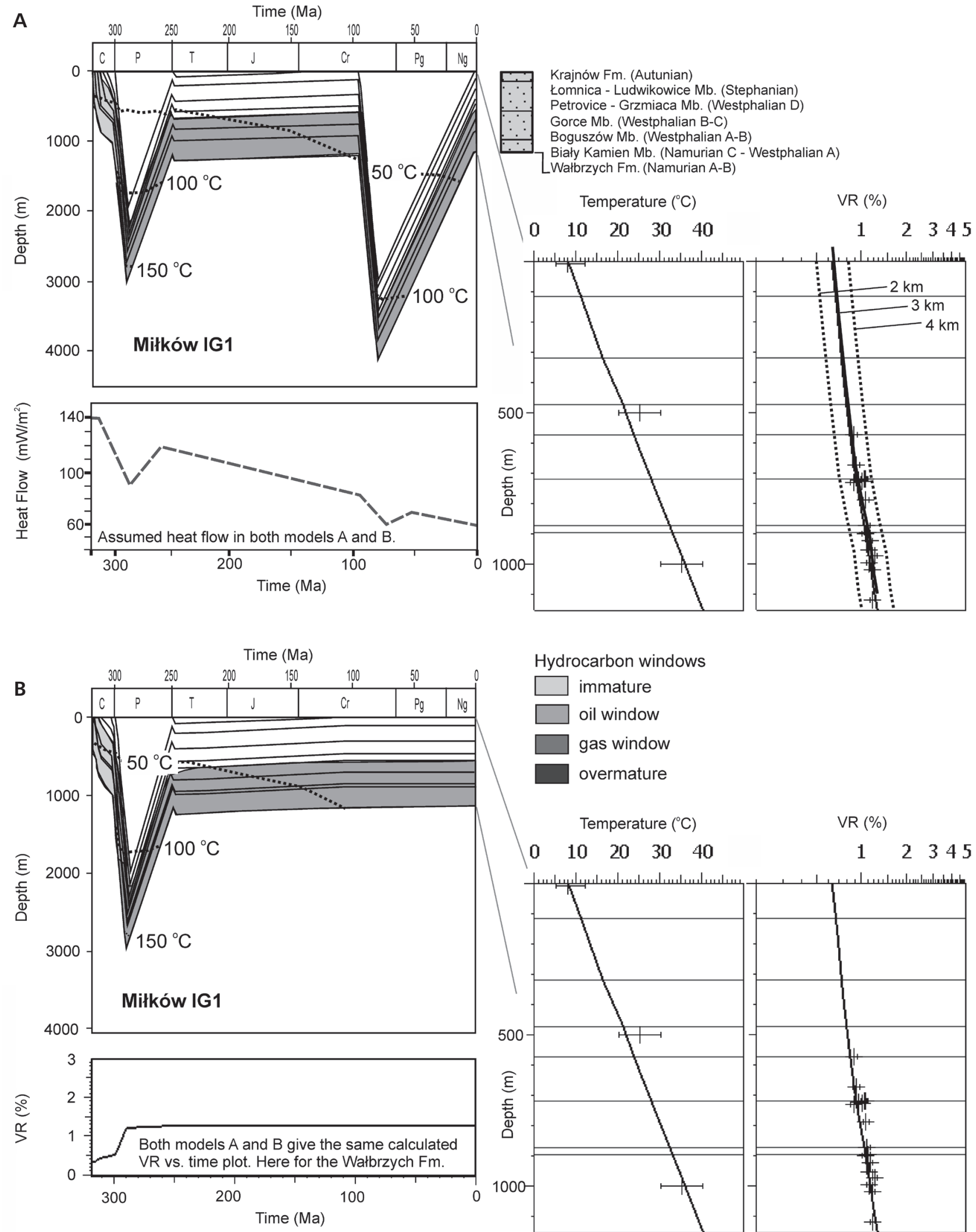

Hydrocarbon windows
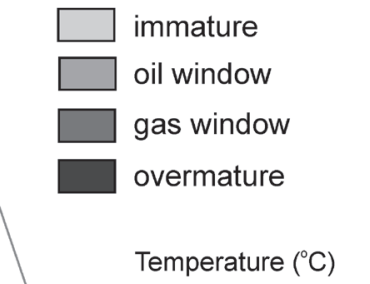

$\begin{array}{lllll}0 & 10 & 20 & 30 & 40\end{array}$

VR $(\%)$

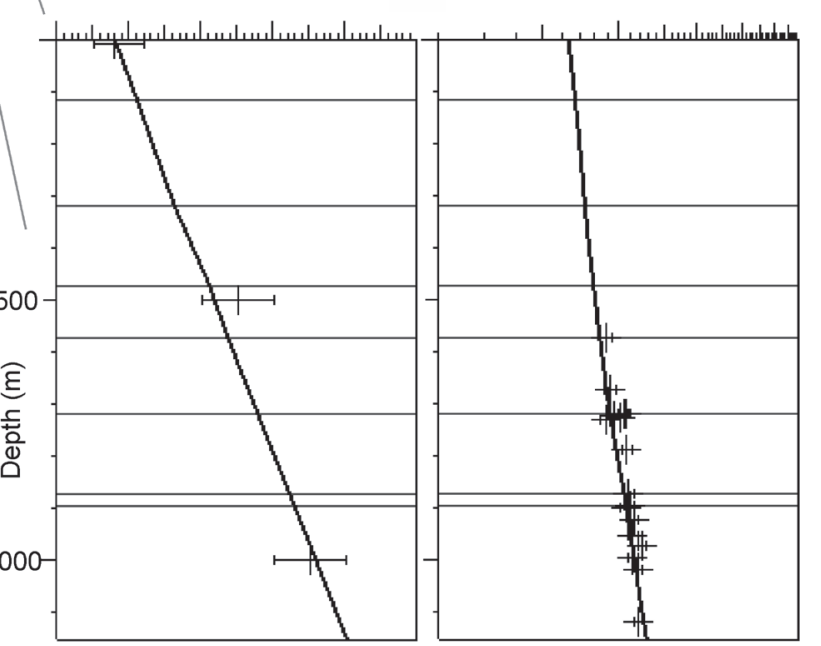

Figure 4. Burial and thermal history model for Miłków IG-1 well. • A - model assuming Cretaceous burial of $c .3 \mathrm{~km}$ (preferred). $\bullet$ B - model assuming only Variscan burial. Both models show the same quality of calibration by present-day temperature and mean vitrinite reflectance. No further increase of coal rank is observed in the Late Cretaceous due to high heat flow in the Palaeozoic. See further explanations in the text. 
A

Time (Ma)

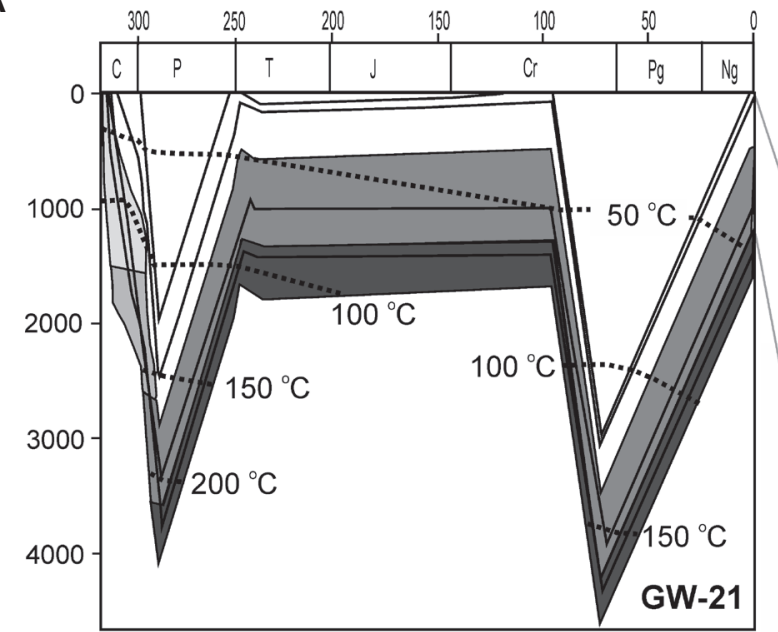
$\because$ Łomnica Mb. (Stephanian A-B)
Petrovice - Grzmiaca Mb. (Westphalian D)
Gorce Mb. (Westphalian B-C)
Boguszów Mb. (Westphalian A-B)
Biały Kamień Mb. (Namurian C - Westphalian A)
Wałbrzych Fm. (Namurian A-B)

$\begin{array}{llc} & \text { Temperature }\left({ }^{\circ} \mathrm{C}\right) \\ 0 & 20 & 40\end{array}$

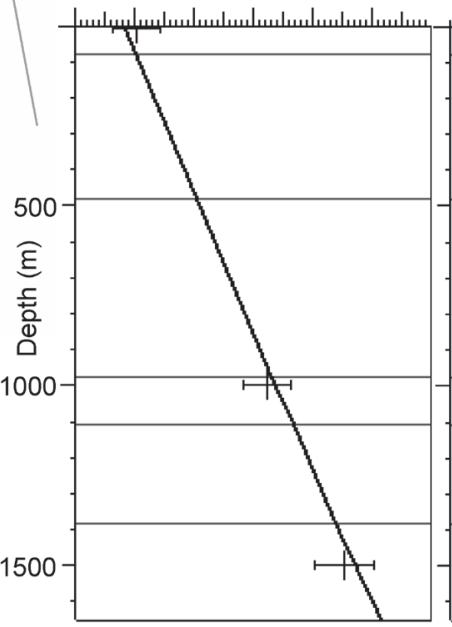

Hydrocarbon windows

B
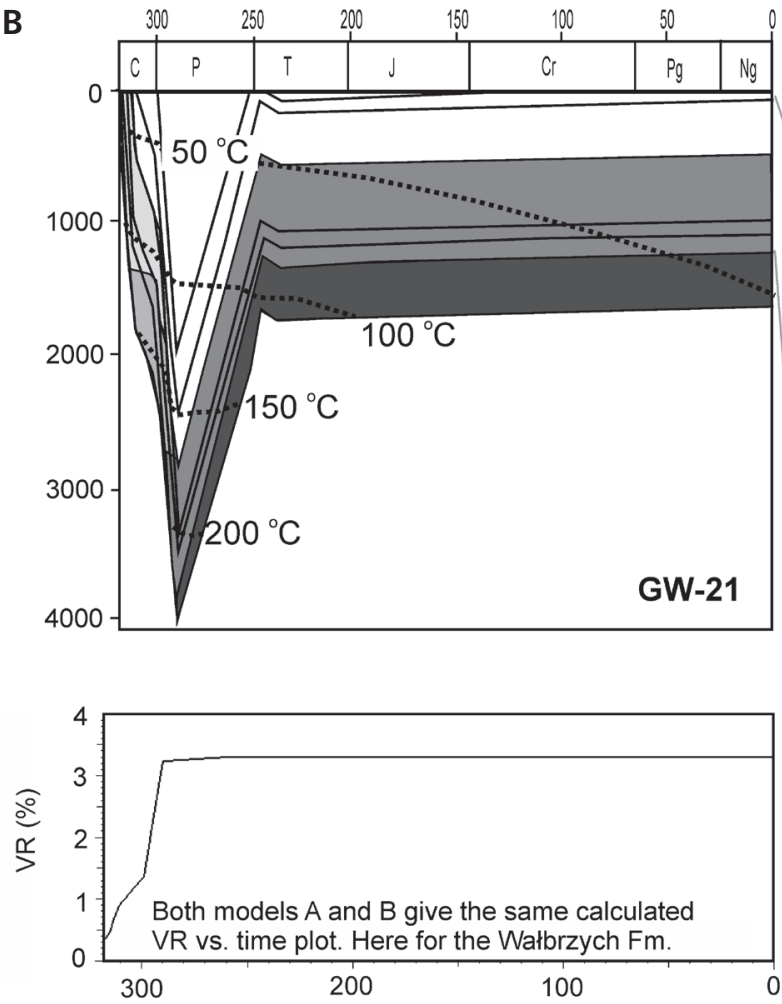

immature

oil window

gas window

overmature

Temperature $\left({ }^{\circ} \mathrm{C}\right)$

$\begin{array}{lll}0 & 20 & 40\end{array}$

VR $(\%)$

12345
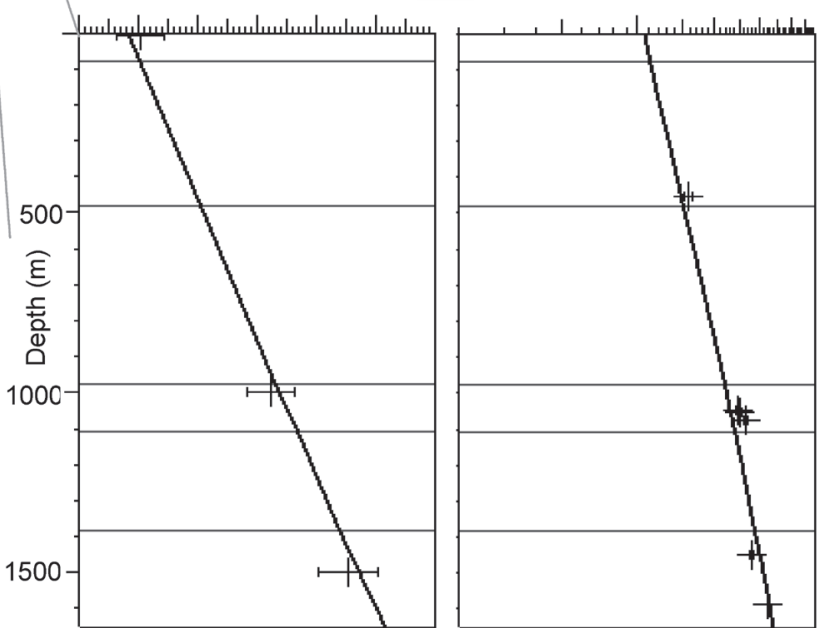

Figure 5. Burial and thermal history model for GW-21 well. $\bullet \mathrm{A}$ - model assuming Cretaceous burial of $c .3 \mathrm{~km}$ (preferred); $\mathrm{B}-$ model assuming only Variscan burial. Both models show the same quality of calibration by present-day temperature and mean vitrinite reflectance. No further increase of coal rank is observed in the Late Cretaceous due to high heat flow in the Palaeozoic. See further explanations in the text. 

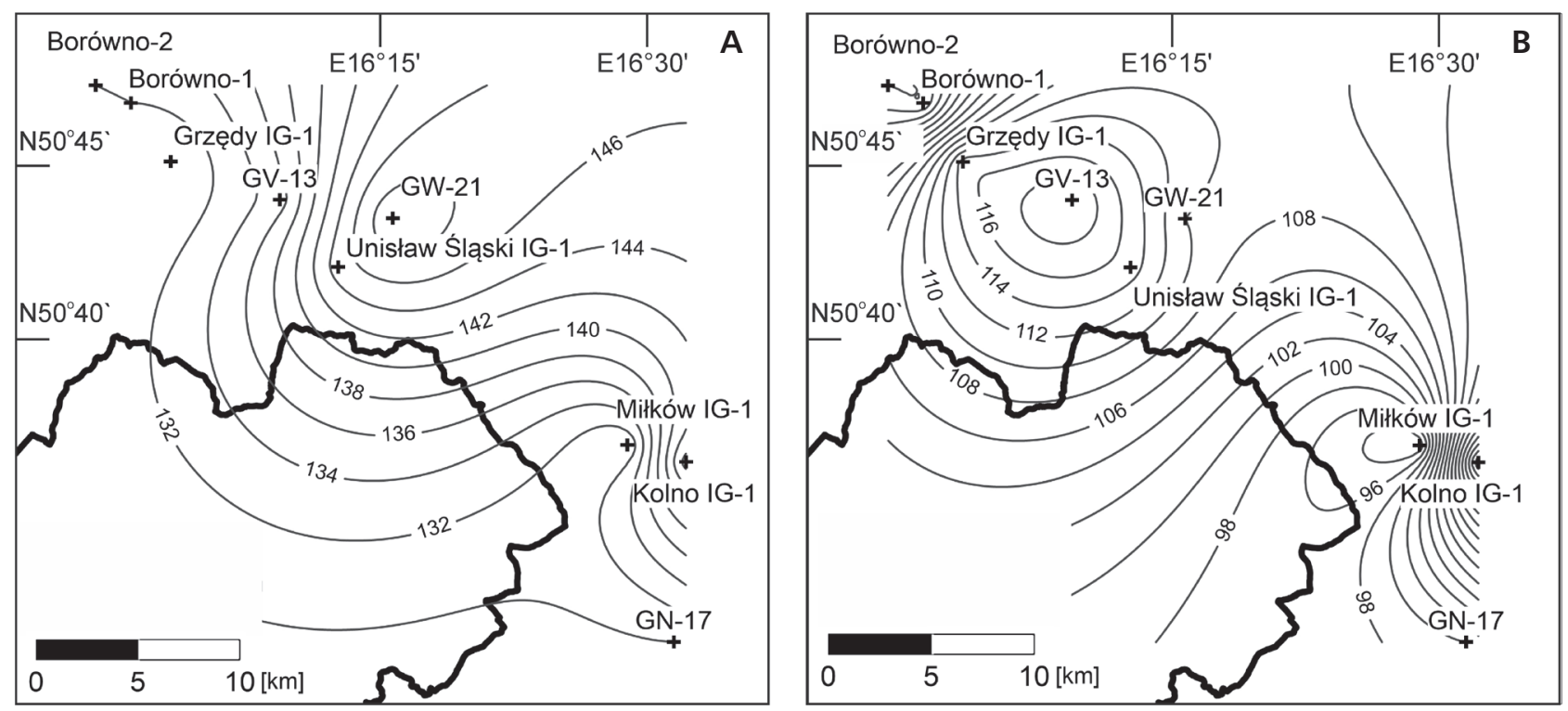

Explanation of symbols: + - well $\hat{\sim}$-Polish-Czech border

Figure 6. Heat flow (in $\mathrm{mW} / \mathrm{m}^{2}$ ) assumed in Carboniferous (A) and in early Permian (B).

temporal framework for modelling (Tab. 1). Geological events, scaled in time, create the structure of a model and govern the data input. The dataset for each event consists of duration, depositional or erosional thickness, lithology, bathymetry, sediment/water interface or surface temperature, and heat flow. Input data also includes the petrophysical parameters of the given lithology and

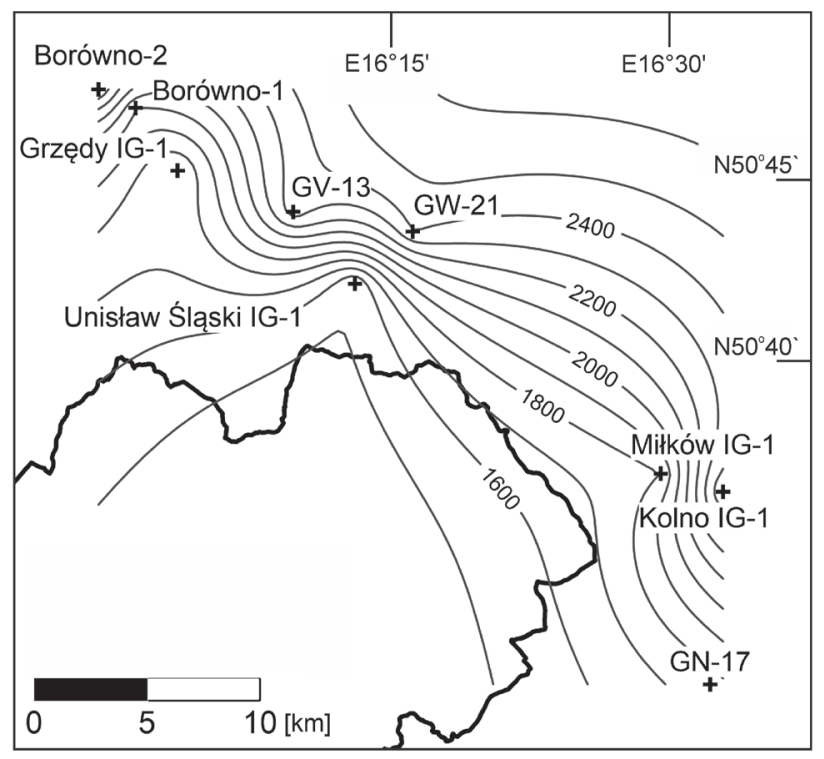

Explanation of symbols: + - well

^ - Polish-Czech border

Figure 7. Exhumed Palaeozoic overburden (in metres). present-day thermal regime (Hantschel \& Kauerauf 2009). Petrophysical parameters were based on the PetroMod library, according to lithology types identified in the analyzed wells (Tab. 1). The backstripping method which includes a decompaction correction was applied to establish the burial history. Thermal boundaries define the thermal regime of the sedimentary basin over time. The most important input parameters are the basal heat flow as the lower thermal boundary, and surface temperature as the upper boundary (Hantschel \& Kauerauf 2009). Different subsidence-uplift scenarios are tested during modelling in order to find a plausible model. The calculated results were compared with the measured values in order to calibrate the model and check its geological reliability. Calibration was performed mainly by varying the heat flow in time or/and the thickness of the now exhumed sedimentary overburden (Waples et al. 1992a, b; Hantschel \& Kauerauf 2009). Initially, heat flow estimates for the past stages of basin history are assigned on the basis of the tectonic setting (Hantschel \& Kauerauf 2009). In the following iterations, the heat-flow values are adjusted through the modelling procedure, in order to achieve the best fit between the calculated model and the measured calibration parameters. Heat flow values are best constrained for times of maximum temperature, which correspond to the maximum burial in many cases (Waples et al. 1992a, Hantschel \& Kauerauf 2009).

A broader discussion of the applied maturity modelling method is provided by, for example, Waples et al. (1992a, b), Hantschel \& Kauerauf (2009), and Botor et al. (2013). 

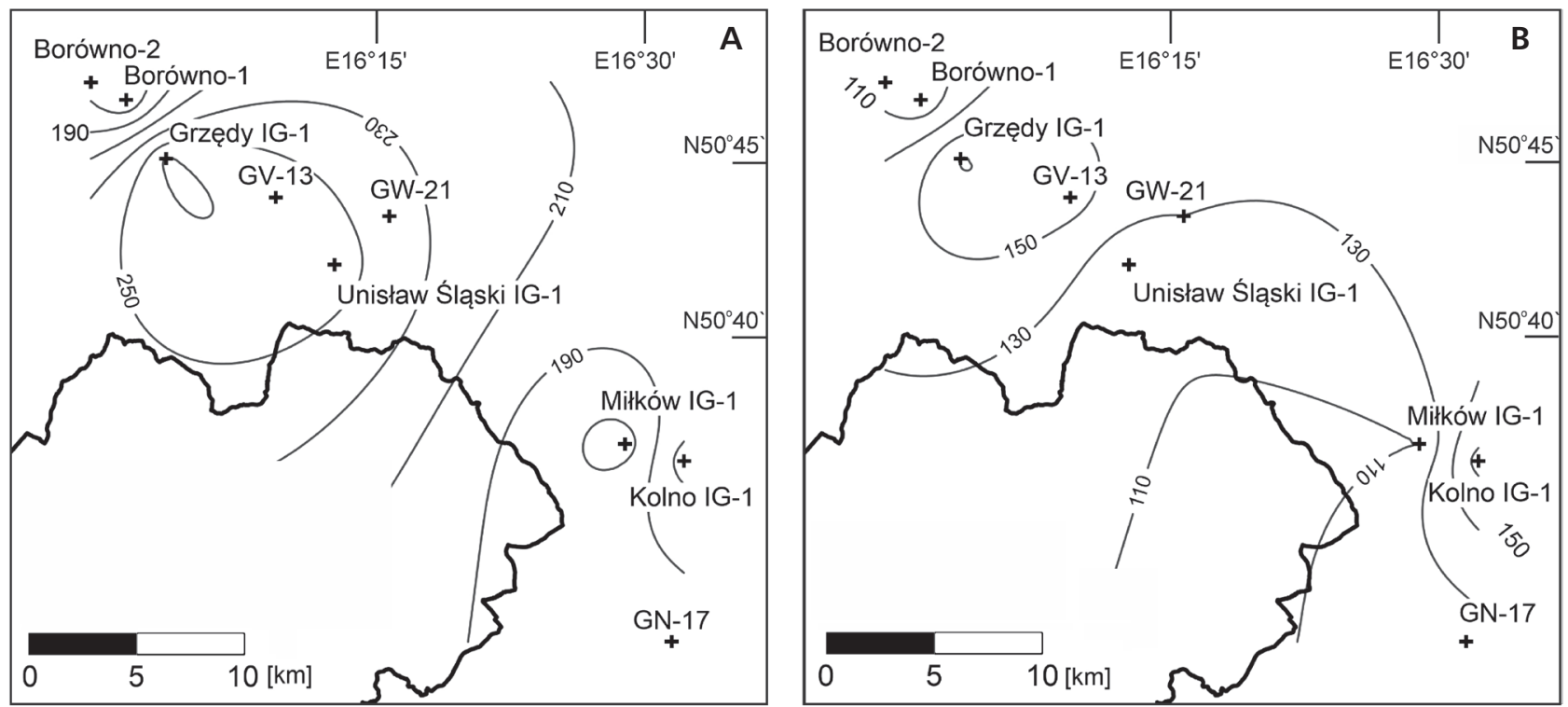

Explanation of symbols: + - well

- Polish-Czech border

Figure 8. Calculated maximum palaeotemperature $\left(\right.$ in ${ }^{\circ} \mathrm{C}$ ) at the bottom of analyzed Carboniferous (A) and at the top of the Carboniferous sections $(\mathrm{B})$.

\section{Results}

The results of maturity modelling for nine well sections are presented in the form of burial-thermal history plots for selected representative wells: GW-21 and Miłków IG-1 (Tab. 1; Figs 4A, B and 5A, B). The well locations are given in Fig. 2 and their conceptual applied model in Tab. 1. In this thermal modelling we applied the thermochronological results in the ISB and adjacent areas (Aramowicz et al. 2006, Danišík et al. 2012, Sobczyk et al. 2015, Botor et al. 2019) suggesting significant Late Cretaceous sedimentary burial in the study area (Figs 4A, $5 \mathrm{~A}$ ). Modelling was initially performed assuming that coalification only resulted from the Variscan processes, however (Figs 4B, 5B). These initial models (Variscan) were based on earlier works on coalification processes
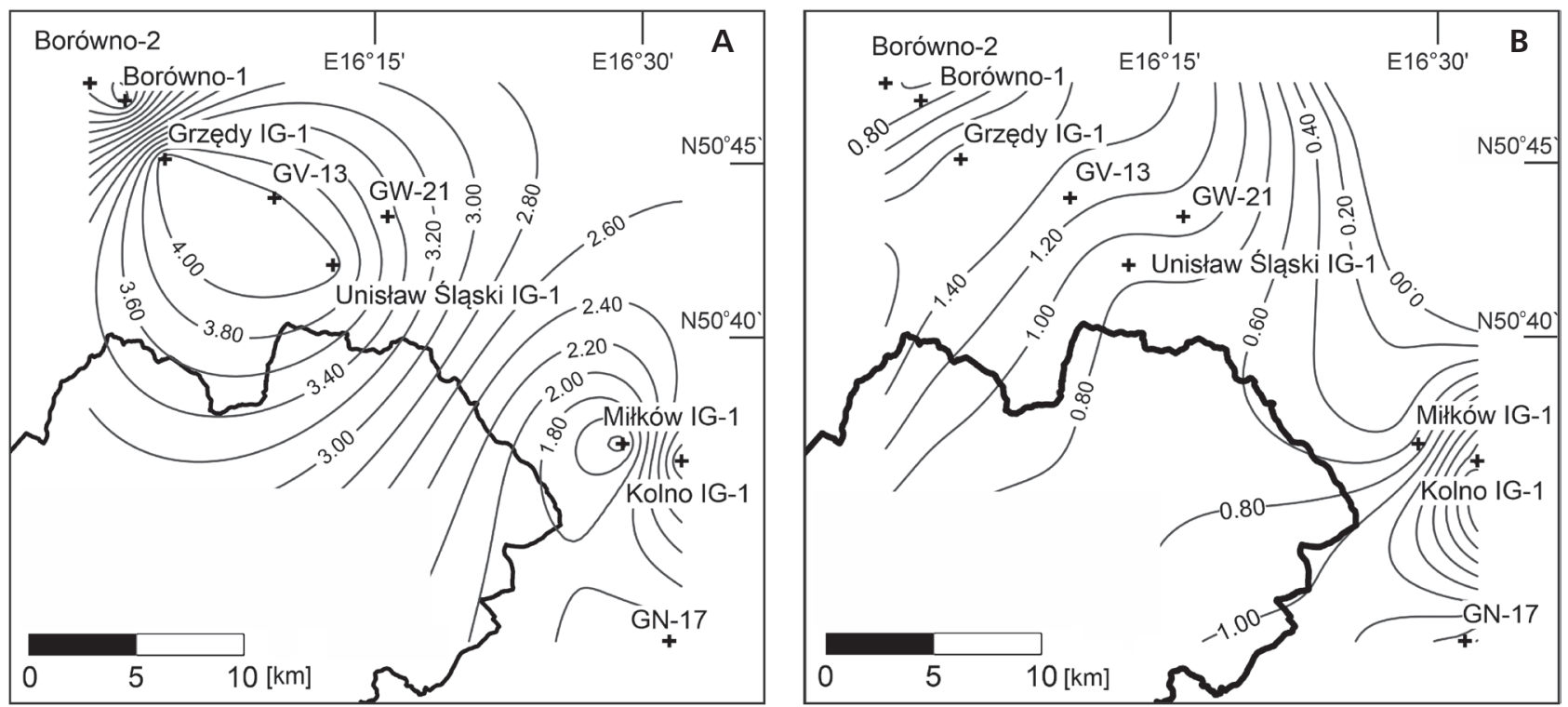

Explanation of symbols: + - well $\sim$-Polish-Czech border

Figure 9. Calculated mean vitrinite reflectance (in \%VR) at the bottom of analyzed Carboniferous (A), and at the top of the Carboniferous (B). 

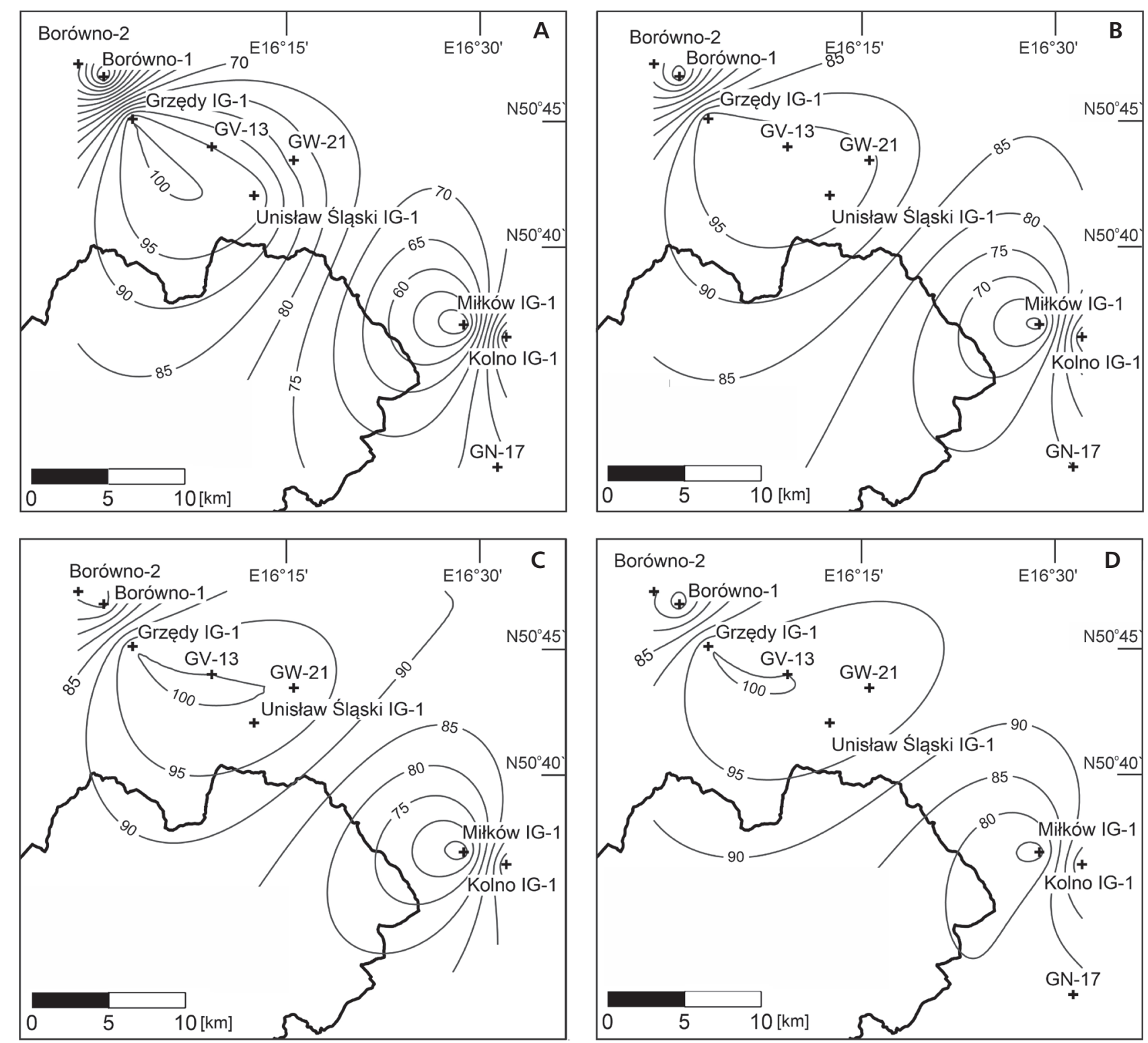

Explanation of svmbols: + - well $\hat{\Lambda}$ - Polish-Czech border

Figure 10. Kerogen transformation ratio (in \%) applying the kinetic model by Pepper \& Corvi (1995) for kerogen D-E III calculated in: A - Wałbrzych Formation; B - Biały Kamień Formation; C - Boguszów Member; and D - Gorce Member of Žaclér Formation.

in the ISB (Kułakowski 1979, Mastalerz \& Jones 1988), which suggested late Carboniferous development. These initial models were the best-fit scenarios, assuming high heat flow and significant burial in late Carboniferous to early Permian. Burial of the analyzed base of the upper Carboniferous, at the end of the Variscan cycle (c. $280 \mathrm{Ma}$ ) probably reached a depth of up to $3-4 \mathrm{~km}$ (Figs 4B, 5B). The lowest burial occurred in the area of the Borówno-1 and Borówno-2 wells, close to the NE margin of the ISB, whilst towards the SE depocentre of the basin, the depth of burial was higher. There are no deep wells suitable for modelling in the southern part of the ISB (Fig. 2). The high heat flow regime was caused by significant magmatic development in the Carboniferous to early Permian, and later heat flow decreased to relatively low present-day values. In these models VR reached maximum values in the early Permian, but with a significant increase in the late Carboniferous (Figs 4B, 5B).

Thermochronological data, however, shows that in the Upper Cretaceous, the ISB and adjacent areas were additionally buried under 3-4 km sedimentary cover (Danišík et al. 2012; Sobczyk et al. 2015, 2020; Botor et al. 2019), and therefore such new scenarios of burial were assumed in the final stage of modelling. The initial models 

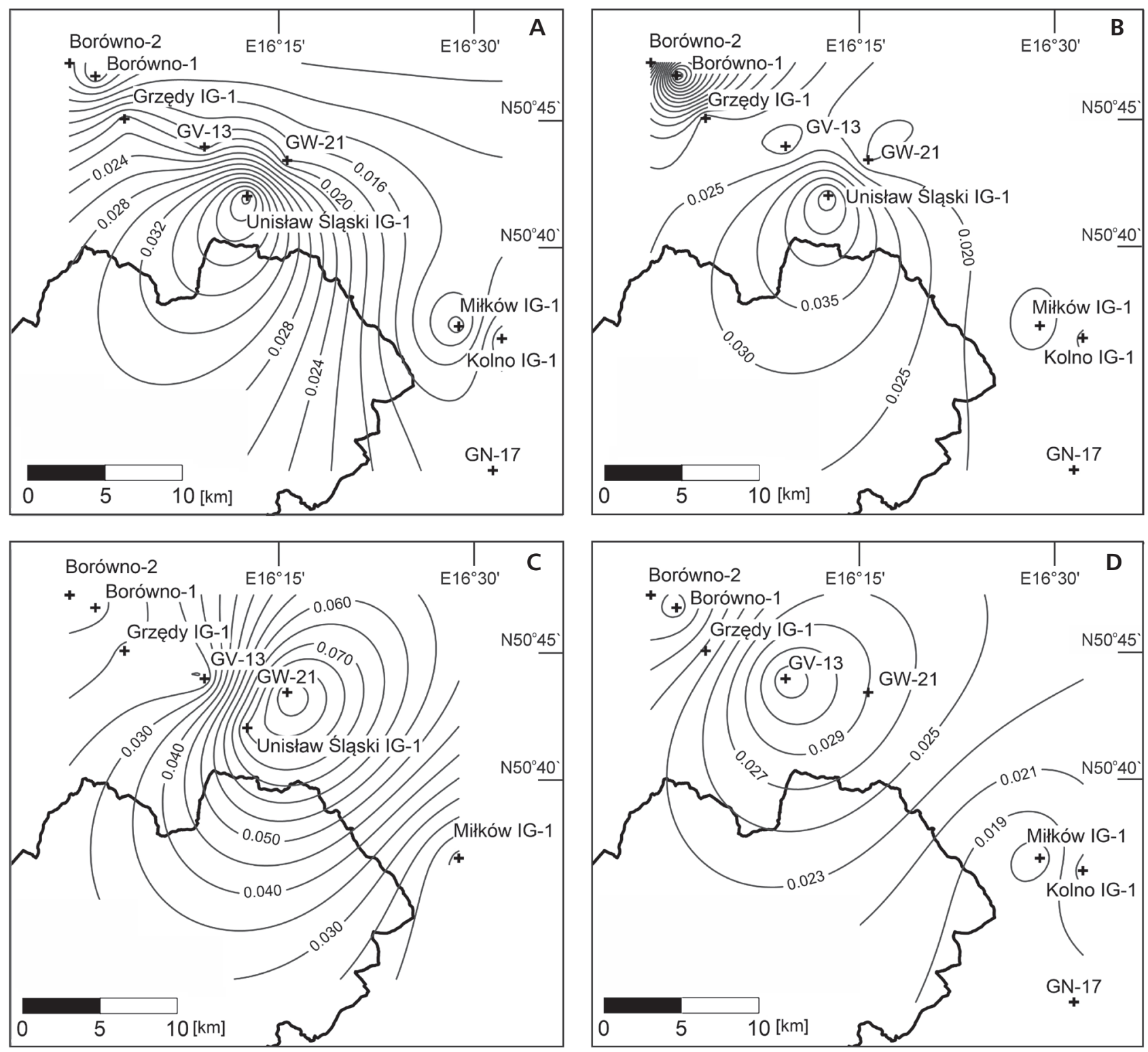

\section{Explanation of symbols: + - well $\wedge$ - Polish-Czech border}

Figure 11. Bulk hydrocarbon generation rate (in grams hydrocarbons per gram total organic carbon per million years) calculated applying the kinetic model by Pepper \& Corvi (1995) for kerogen D-E III calculated in: A - Wałbrzych Formation; B - Biały Kamień Formation; C - Boguszów Member; and D - Gorce Member of Žacléř Formation.

were supplemented by c. $3 \mathrm{~km}$ of Late Cretaceous burial (Tab. 1; Figs 4A, 5A). The heat flow regime was left as in the initial models. Such scenarios did not affect VR change, due to high heat flow in the Late Palaeozoic, however, presumably at least $4.5-5.0 \mathrm{~km}$ or more Late Cretaceous burial would be necessary for increasing the VR of the Carboniferous strata in the Cretaceous time. However, the lack of reset of zircon helium ages in the ISB (Sobczyk et al. 2015,2020 ) is definitely against such a hypothesis, because zircon helium age reset requires temperature ranging from $c .140-200{ }^{\circ} \mathrm{C}$. The low thermal maturity of c. $0.4 \% \mathrm{VR}$, which suggests a palaeotemperature below $70{ }^{\circ} \mathrm{C}$ in the Cretaceous sediments in adjacent areas of the Sudetes (e.g. Wagner 2013), also indicates that temperature in the Cretaceous was not sufficient to cause further coalification in the Carboniferous strata.

Heat flow in the Carboniferous to early Permian was high, due to the development of magmatic processes (Figs 4, 5). In the models presented, heat flow successively declined with increasing burial (during late Carboniferous to early Permian), as the rate of heat flow decrease is proportional to the rate of subsidence (Carr \& Uguna 2015). 
Heat flow then increased immediately during the inversion phase (here in the mid-Permian). The increasing upward force is associated with an increase of heat flow (Carr \& Uguna 2015). Finally, heat flow decreased to presentday values (Figs 4, 5). Heat flow in the Cretaceous was much lower than in the Palaeozoic because there was no magmatic or hydrothermal processes known to be develop in Cretaceous time. Tertiary volcanic processes were only active to the north of the ISB (e.g. Birkenmajer et al. 2004), but these did not affect thermal conditions in the ISB, as documented by AFT data (Botor et al. 2019).

A series of maps of heat flow, exhumed overburden, maximum palaeotemperature, vitrinite reflectance, kerogen transformation ratio, and bulk hydrocarbons generation rate were calculated based on 1-D modelling results (Figs $6-11)$. The heat flow is assumed as $130-150 \mathrm{~mW} / \mathrm{m}^{2}$ in the Carboniferous, and $90-120 \mathrm{~mW} / \mathrm{m}^{2}$ in the Permian (Fig. 6). Variscan exhumation is calculated as $1600 \mathrm{~m}$ to $2400 \mathrm{~m}$, increasing towards the margin of the ISB (Fig. 7). The Carboniferous rocks reached their peak temperature during the early Permian. The bottom of the analyzed upper Carboniferous strata was heated to a minimum of $150-170{ }^{\circ} \mathrm{C}$ near the margin of the ISB (Miłków IG-1 and Borówno areas) and above $250{ }^{\circ} \mathrm{C}$ in the deeper, central part of the ISB. At the top of the Carboniferous, the maximum temperature was between $90-110^{\circ} \mathrm{C}$ close to the margin, and more than $150{ }^{\circ} \mathrm{C}$ in the more central parts of the ISB (Fig. 8). A similar estimation of temperature, using combined Raman spectroscopy and VR data, was given by Botor et al. (2020), and using VR data by Mastalerz \& Jones (1988). This heating is reflected in the distribution of VR values. VR has been calculated over $4.0 \%$ for the bottom of the Carboniferous sections in the areas between the Grzędy IG-1 and Unisław Śląski IG-1 wells, whereas at the top of the Carboniferous VR values reached c. 1.2-1.4\% in the same area (Fig. 9).

Coal and dispersed sedimentary organic matter within the upper Carboniferous sediments of the ISB are predominantly of terrestrial origin (gas-prone type III kerogen) (Kotarba \& Rice 2001). Pepper and Corvi's (1995) III-DE kinetic model of hydrocarbon generation was therefore applied. The kerogen transformation and hydrocarbon generation mainly took place during the late Carboniferous and early Permian, reaching a maximum before tectonic inversion in the early Permian. The scope of advanced hydrocarbon generation processes is best represented by the transformation ratio (TR, transformation ratio, expressed in \%) showing the degree of thermogenic transformation of kerogen, which undergoes processes of hydrocarbon generation (e.g. Hantschel \& Kauerauf 2009). In the upper Carboniferous strata, the lowest TR values occur along the NW margin of ISB (Borówno-1 well, 19\%), and increase towards the SE. The second local minimum is represented by the Miłków IG-1 well section, which has slightly higher values than Borówno-1. The maximum TR values were calculated for the area between the Grzędy IG-1 and Unisław Śląski IG-1 wells, where TR values are above $90 \%$. This TR pattern is similar in all four sedimentary units analyzed (Gorce Mb., Boguszów Mb. Biały Kamień Fm. and Wałbrzych Fm.; Fig. 10A-D). The bulk hydrocarbon generation rate, calculated at the end of the early Permian, reached values from 0.004 to 0.098 grams of hydrocarbons per gram of total organic carbon per million years (Fig. 11A-D).

\section{Discussion}

In the North-Sudetic Basin, which is located north of the analyzed ISB (Fig. 1B), intercalations and thin metalignite and sub-bituminous coal seams, up to $0.5 \mathrm{~m}$ in thickness, occur in shales in the lowest and the highest horizons of the Santonian strata (Milewicz 1997, Wagner 2013). These coals have a VR value equal to 0.37 to $0.42 \%$ (Wagner 2013), which indicates that the Cretaceous sediments were heated at maximum to $c .70^{\circ} \mathrm{C}$ after deposition (using the Barker \& Pawlewicz 1994 method). It therefore required at least $2 \mathrm{~km}$ burial assuming the present-day geothermal gradient of $24{ }^{\circ} \mathrm{C} / \mathrm{km}$ (Bruszewska 2000) and the average Cretaceous surface temperature of $20^{\circ} \mathrm{C}$ (e.g. Thomson $\&$ Zeh 2000). The results of apatite helium dating from Triassic sandstones of North-Sudetic Basin also revealed that all apatite grains experienced post-depositional thermal resetting, which took place during the Late Cretaceous. This thermal event recorded by the apatite helium ages could be roughly related to the exhumation of at least $1.5-2 \mathrm{~km}$ of Late Cretaceous strata due to tectonic inversion (Sobczyk et al. 2018).

Towards the S and SE of the Sudetes, the Cretaceous cover was probably thicker (Danišík et al. 2012, Sobczyk et al. 2015). In the ISB Late Cretaceous to Palaeogene, apatite fission track ages for the Carboniferous, Triassic and Cenomanian-Turonian samples indicate a post-depositional thermal event exceeding $c .110-120^{\circ} \mathrm{C}$, which was followed by cooling after Turonian (Botor et al. 2019). Considering that the zircon helium ages of Cretaceous samples are not reset (Sobczyk et al. 2015), it shows that the maximum temperature in the Cretaceous sediments was below $c .130-150{ }^{\circ} \mathrm{C}$ (below the sensitivity of the zircon helium thermochronometer). Collectively this data suggests that the maximum temperature experienced by Cretaceous strata was in the range c. $110-130{ }^{\circ} \mathrm{C}$ in the ISB (Danišík et al. 2012, Sobczyk et al. 2015, Botor et al. 2019). The temperature in the Carboniferous strata was thus not higher than this range during the Cretaceous burial. The estimated values $\left(c .110-130{ }^{\circ} \mathrm{C}\right)$ are much lower than maximum palaeotemperatures that occurred 
in the latest Carboniferous and/or early Permian times (compare Figs 4, 5 and 8).

In the ISB, these maturity modelling results confirm earlier works (Kułakowski 1979, Mastalerz \& Jones 1988, Botor et al. 2019) showing that a temperature maximum in the Carboniferous strata was likely achieved in the late Carboniferous to early Permian. This Variscan thermal peak was followed by slow cooling in the late PermianMesozoic, re-heating during Late Cretaceous burial, and the final acceleration of cooling in the Late CretaceousPalaeogene (Botor et al. 2019). Generally, the thermal models based on apatite fission tracks and zircon helium data postulate significant mid-Cretaceous burial in the entire Sudetes (Danišík et al. 2010, 2012; Sobczyk et al. 2015, 2018, 2020; Botor et al. 2019). Neither the tested models, however, nor measured AFT data show any reheating in the Cenozoic in the ISB (Botor et al. 2019) in association with Neogene volcanism present in the Sudetes (e.g. Birkenmajer et al. 2004).

The thermal maturity of organic matter occurring in the Carboniferous sediments of the ISB is generally high (usually c. 1-4\%VR), which demonstrates maximum temperatures much above $c .120^{\circ} \mathrm{C}$. The thermochronological data (Danišík et al. 2012; Sobczyk et al. 2015, 2020; Botor et al. 2019) shows that the Cretaceous rocks presently exposed on the surface were at depths of c. 3-4 km during the mid-Late Cretaceous, assuming the present-day geothermal gradient of $24{ }^{\circ} \mathrm{C} / \mathrm{km}$ (Bruszewska 2000) and an average Cretaceous surface temperature of $20^{\circ} \mathrm{C}$ (e.g. Thomson \& Zeh 2000). In this maturity modelling, the exhumed Cretaceous overburden is therefore assumed to be $c .3 \mathrm{~km}$ on average. In the absence of data confirming a high heat flow regime in the Late Cretaceous, a sedimentary burial hypothesis seems to be the most plausible. The deposition of sedimentary overburden responsible for Late Cretaceous re-heating was related to Cenomanian transgression over the northern part of the Bohemian Massif (Skoček \& Valečka 1983, Milewicz 1997). Thereafter, the basin was inverted in the late Cretaceous. The late Turonian to early Campanian (c. 80-90 Ma) onset of the tectonic inversion of the ISB, suggested by thermochronological data (Botor et al. 2019, Sobczyk et al. 2020), was coeval with cooling due to tectonic inversion in the Holy Cross Mountains and adjacent areas of the Mid-Polish Trough documented by thermochronological data (Botor et al. 2018: fig. 3b, c; Łuszczak et al. 2020). The seismic investigation results along the Mid-Polish Trough also suggest similar timing for the onset of tectonic inversion (Krzywiec et al. 2018). This timing of inversion is identical (within the limits of resolution) to inversion of Variscan massifs and Mesozoic basins (e.g. Ziegler \& Dèzes 2007). The data above shows that in the late Cretaceous, but definitely long before the Maastrichtian, the crust in the central Europe was subject to a compressive to transpressional regime (e.g. Kley \& Voigt 2008). It caused a reactivation of Variscan faults (Scheck et al. 2002), exhumation of tectonic blocks and finally inversion of the Cretaceous basins (Skoček \& Valečka 1983; Aramowicz et al. 2006; Kley \& Voigt 2008; Ventura et al. 2009; Danišík et al. 2010, 2012; Sobczyk et al. 2015, 2020; Botor et al. 2019).

The results of this work are similar to those reported by Suchý et al. (2019) who also imply elevated Late Palaeozoic thermal gradients $\left(\right.$ c. $\left.200{ }^{\circ} \mathrm{C} / \mathrm{km}\right)$ in the coalbearing basins of the northern Czechia that have a similar geotectonic position as the ISB. The very high Variscan heat flow could have been due to thinning of the lithosphere and abundant magmatic/volcanic activity (e.g. Dvořák \& Paproth 1988, Henk et al. 2000, Awdankiewicz 2004, Ulrych et al. 2004, Suchý et al. 2019). In the ISB many intrusive bodies, which penetrated both Carboniferous and Permian strata, are widely known (e.g. Awdankiewicz 2004). It can therefore be inferred that a high heat flow regime also operated in the Late Palaeozoic along the NE margin of the Bohemian Massif. Another factor potentially affecting the coal rank is fluid flow event(s). High palaeogeothermal gradients can be enhanced by hot fluids, particularly along faults or thrusts, resulting in rapid coalification (e.g. Hower \& Gayer 2002). The modelling approach used in this study cannot detect such short-lived convection processes in the crust, but the results do not contradict their existence.

In Late Palaeozoic, the Carboniferous sediments were subject to intense subsidence and rapid burial up to the early Permian, and were then subjected to tectonic inversion. The Variscan coalification processes resulted in natural gas generation (dry gas, methane dominated). The upper Carboniferous strata are mainly characterized by an early to late phase of hydrocarbon generation. The kerogen transformation ratio (c. 19-100\%) is variable across the ISB (Fig. 10). The bulk hydrocarbon generation rate reached c. 0.080 grams of hydrocarbons per gram of total organic carbon per million years (Fig. 11). The generation of hydrocarbons took place only during the Palaeozoic burial, prior to $280 \mathrm{Ma}$. During the Mesozoic, sedimentary burial did not result in any additional hydrocarbon generation. As a result, there was a widespread dispersion of the generated hydrocarbons. Significant volumes of previously generated thermogenic gases within the coal seams and in siltstones/claystones were released into the atmosphere.

\section{Conclusions}

The maturity modelling results indicate that the studied coal-bearing upper Carboniferous strata in the ISB were heated to temperatures $c .100-260{ }^{\circ} \mathrm{C}$ in the late 
Carboniferous to early Permian, which is in accordance with the high level of thermal maturity of the organic matter within Carboniferous rocks. VR values range from c. $0.6 \%$ to over $4.5 \%$. There was a second phase of significant (c. $3 \mathrm{~km}$ ) sedimentary burial during the Late Cretaceous. This phase, however, occurred in a low heat flow regime. The late Carboniferous-early Permian magmatic activity (e.g. Awdankiewicz 2004) was the reason for the high heat flow (c. $\left.90-150 \mathrm{~mW} / \mathrm{m}^{2}\right)$, and together with significant sedimentary burial in the late Carboniferous affected the coalification processes of upper Carboniferous organic matter. The coalification process had already started at a shallow burial depth due to highly elevated Variscan heat flow (Pešek \& Sýkorová 2006). The major coalification phase of the Namurian-Westphalian coal seams could have occurred in the latest Carboniferous to early Permian. It was interrupted by the tectonic inversion of the basin. Later phases of temperature increase caused by late Cretaceous burial did not surpass the temperatures that occurred in the Carboniferous strata in the late Palaeozoic. The Mesozoic temperature increase does not therefore appear to have had any noticeable effect on the maturation of the Carboniferous organic matter, and hydrocarbon generation in the ISB. The Variscan coalification processes resulted in the formation of methane-dominated natural gas. The upper Carboniferous coal-bearing strata are characterized chiefly by the main to late phase of hydrocarbon generation. The kerogen transformation ratio values vary across the basin, ranging from 19 to $100 \%$ TR.

\section{Acknowledgements}

I thank Václav Suchý, Jiří Laurin and Zuzana Tasáryová for their valuable input, which improved the quality of the paper. This work was partially supported by AGH statutory grant no. 16.16.140.315.

\section{References}

Allen, P.A. \& Allen, J.R. 1990. Basin Analysis. Principles \& Applications. 451 pp. Blackwell Scientific, Oxford.

Aramowicz, A., Anczkiewicz, A.A. \& Mazur, S. 2006. Fission track dating of apatites from the Góry Sowie Massif, Polish Sudetes, NE Bohemian Massif: Implications of post-Variscan denudation and uplift. Neues Jahrbuch für Mineralogie Abhandlungen 182, 221-229.

DOI 10.1127/0077-7757/2006/0046

Awdankiewicz, M. 2004. Sedimentation, volcanism and subvolcanic intrusions in a late Palaeozoic intramontane trough (the Intra-Sudetic Basin, SW Poland). Geological Society London, Special Publication 234, 5-11.

DOI 10.1144/GSL.SP.2004.234.01.02
Awdankiewicz, M., Kurowski, L., Mastalerz, K. \& Raczyński, P. 2003. The Intra Sudetic Basin: record of sedimentary and volcanic processes in late- to post-orogenic setting. Geolines 16, 165-183.

Barker, C.E. \& Pawlewicz, M.J. 1994. Calculation of Vitrinite Reflectance from Thermal Histories and Peak Temperatures, 216-229. In Mukhopadhyay, P.K. \& Dow, W.G. (eds) Vitrinite Reflectance as a Maturity Parameter. Applications and Limitations, ACS Symposium Series 570. American Chemical Society, Washington DC. DOI 10.1021/bk-1994-0570.ch014

Birkenmajer, K., Pécskay, Z., Grabowski, J., Lorenc, M.W. \& ZAGOŻDżon, P.P. 2004. Radiometric dating of the Tertiary volcanics in Lower Silesia, Poland. IV. Further K-Ar and palaeomagnetic data from Late Oligocene to Early Miocene basaltic rocks of the Fore-Sudetic Block. Annales Societatis Geologorum Poloniae 74, 1-19.

Bossowski, A. 1995. Coal Deposits - Lower Silesian Coal Basin, 173-175. In Zdanowski, A. \& Żakowa, H. (eds) The Carboniferous System in Poland. Prace Państwowego Instytutu Geologicznego 148.

Bossowski, A. 1996. Grzędy IG-1. Profile Gtębokich Otworów Państwowego Instytutu Geologicznego 83, 1-55.

Bossowski, A. 1997. Unisław Śląski IG-1. Profile Gtębokich Otworów Państwowego Instytutu Geologicznego 88, 1-64.

Bossowski, A. 2001. Kolno IG-1. Profile Głębokich Otworów Państwowego Instytutu Geologicznego 99, 1-50.

Bossowski, A. \& Innatowicz, A. 2006. Geological atlas of the Lower Silesian Coal Basin. Państwowy Instytut Geologiczny, Warsaw.

Bossowski, A., Ihnatowicz, A., Kurowski, L., Mastalerz, K. \& NowAK, G.J. 1995. Lithostratigraphy and sedimentologicpaleogeographic development. Intra-Sudetic Depression, 142-147. In Zdanowski, A. \& Żakowa, H. (eds) The Carboniferous System in Poland. Prace Państwowego Instytutu Geologicznego 148.

Botor, D., ToboŁa, T. \& WaliczeK, M. 2020. Thermal history of Carboniferous shales in the northern part of the Intra-Sudetic Basin (Sudetes, Poland) based on Raman spectroscopy and vitrinite reflectance of dispersed organic matter. Acta Geologica Polonica 70(3), 363-396.

DOI 10.24425/agp.2019.126463

Botor, D., Anczkiewicz, A.A., Dunkl, I., Golonka, J., Paszkowski, M. \& Mazur, S. 2018. Tectonothermal history of the Holy Cross Mountains (Poland) in the light of low temperature thermochronology. Terra. Nova 30, 270-278. DOI 10.1111/ter.12336

Botor, D., Anczkiewicz, A., Mazur, S. \& Siwecki, T. 2019. PostVariscan thermal history of the Intra-Sudetic Basin (Sudetes, Bohemian Massif) based on apatite fission track analysis. International Journal of Earth Sciences 108, 2561-2576. DOI 10.1007/s00531-019-01777-9

Botor, D., Dunkl, I., Anczkiewicz, A.A. \& Mazur, S. 2017. Post-Variscan thermal history of the Moravo-Silesian lower Carboniferous Culm Basin (NE Czech Republic - SW Poland). Tectonophysics 712-713, 643-662.

DOI 10.1016/j.tecto.2017.06.035 
Botor, D., Papiernik, B., Maćkowski, T., Reicher, B., Kosakowski, P., Machowski, G. \& Górecki, W. 2013. Gas generation in the Carboniferous source rocks of the Variscan and their foreland: implications for a charge history of natural gases of the Rotliegend deposits. Annales Societatis Geologorum Poloniae 83, 353-383.

BruszewsKa, B. 2000. The geothermal conditions in Lower Silesia (SW Poland). Przegląd Geologiczny 48, 639-643.

Burnham, A.K., Peters, K.E. \& Schenk, O. 2017. Evolution of Vitrinite Reflectance Models. Search and Discovery Article \#41982 (2017). http://www.searchanddiscovery.com/pdfz/ documents/2017/41982burnham/ndx_burnham.pdf.html

CARR, A.D. \& UGuna, C.N. 2015. Some thoughts on the influence of pressure and thermal history assumptions on petroleum systems modeling. Journal of Petroleum Geology 38, 459-465. DOI 10.1111/jpg.12621

Chruściel, Z., ŁonaK, J., Skowronek, E. \& Dadok, U. 1985, Petrographic structure and coalification degree of coals from studied wells of Lower Silesian Coal Basin, 223-242. In Proceeding of 2nd Conference "Geology of the Lower Silesian Coal Basin", Watbrzych.

Dalla Torre, M., Ferreiro Mählmann, R. \& Ernst, W.G. 1997. Experimental study on the pressure dependence of vitrinite maturation. Geochimica et Cosmochimica Acta 61, 2921-2928. DOI 10.1016/S0016-7037(97)00104-X

DANIŠ́́K, M., ŠTĚPANČ́́KOVÁ, P. \& Evans, N.J. 2012. Constraining long-term denudation and faulting history in intraplate regions by multi-system thermochronology - an example of the Sudetic Marginal Fault (Bohemian Massif, Central Europe). Tectonics 31(2), 1-19. DOI 10.1029/2011TC003012

Danišík, M., Migoń, P., Kuhlemann, J., Evans, N.J., Dunkl, I. \& FrISCH, W. 2010. Thermochronological constraints on the long-term erosional history of the Karkonosze Mts., Central Europe. Geomorphology 117, 78-89.

DOI 10.1016/j.geomorph.2009.11.010

DVoř́́, J. \& PAPROTH, E. 1988. Trends of the Variscan development near the SW border of the East European Platform. Zeitschrift für Angewandte Geologie 34, 353-359.

Dziedzic, K. \& Teisseyre, A.K. 1990. The Hercynian molasse and younger deposits in the Intra-Sudetic Basin, SW Poland. Neues Jahrbuch fur Geolgie und Paläontologie Abhandlungen 197, 285-305.

Ferreiro Mählmann, R. \& Le Bayon, R. 2016. Vitrinite and vitrinite like solid bitumen reflectance in thermal maturity studies: Correlations from diagenesis to incipient metamorphism in different geodynamic settings. International Journal of Coal Geology 157, 52-73. DOI 10.1016/j.coal.2015.12.008

Filip, J. \& SuchÝ, V. 2004. Thermal and tectonic history of the Barrandian Lower Paleozoic, Czech Republic: is there a fission-track evidence for Carboniferous-Permian overburden and pre-Westphalian alpinotype thrusting? Bulletin of Geosciences 79, 107-112.

Glasmacher, U.A., Mann, U. \& Wagner, G.A. 2002. Thermotectonic evolution of the Barrandian, Czech Republic, as revealed by apatite fission-track analysis. Tectonophysics 359, 381-402. DOI 10.1016/S0040-1951(02)00538-3
Hantschel, T. \& Kauerauf, A. 2009. Fundamentals of Basin and Petroleum Systems Modeling. 476 pp. Springer, Heidelberg.

Henk, A., Blanckenburg, F. von, Finger, F., Schaltegger, U. \& Zulauf, G. 2000. Syn-convergent high-temperature metamorphism and magmatism in the Variscides: a discussion of potential heat sources, 387-399. In Franke, W., HAAK, V., Oncken, O. \& TANner, D. (eds) Orogenic Processes: Quantification and Modelling in the Variscan Belt. Geological Society London, Special Publication 179.

DOI 10.1144/GSL.SP.2000.179.01.23

Hower, J.C. \& GAYer, R.A. 2002. Mechanism of coal metamorphism: case studies from Paleozoic coalfields. International Journal of Coal Geology 50, 215-245.

DOI 10.1016/S0166-5162(02)00119-2

HuANG, W.L. 1996. Experimental study of vitrinite maturation: Effect of temperature, time, pressure, water, and hydrogen index. Organic Geochemistry 24, 233-241.

Innatowicz, A. 2001. Miłków IG-1. Profile Gtębokich Otworów Państwowego Instytutu Geologicznego 98, 1-58. DOI 10.1016/0146-6380(96)00032-0

Kley, J. \& Voigt, T. 2008. Late Cretaceous intraplate thrusting in central Europe: effect of Africa-Iberia-Europe convergence, not Alpine collision. Geology 36, 839-842. DOI 10.1130/G24930A.1

Kotarba, M.J. \& Rice, D.D. 2001. Composition and origin of coalbed gases in the Lower Silesian basin, southwest Poland. Applied Geochemistry 16, 895-910. DOI 10.1016/S0883-2927(00)00058-5

Krzywiec, P., Stachowska, A. \& Stypa, A. 2018. The only way is up-on Mesozoic uplifts and basin inversion events in SE Poland. Geological Society London, Special Publication 469, 33-57. DOI 10.1144/SP469.14

KuŁakowski, T. 1979. Geological environments of coalification of the Žaclér Beds in the Lower Silesian Coal Basin. Geologia Sudetica 14, 103-139.

KWIEcińsKA, B. 1967. The coked coals from the Wałbrzych District. Prace Mineralogiczne Polskiej Akademii Nauk 9, $1-81$.

KwIecińsKa, B. \& NowaK, G.J. 1997. Highly metamorphosed coals from the Lower Silesian Coal Basin (SW Poland), 247-255. In Proceedings of the $13^{\text {th }}$ International Congress: Carboniferous-Permian, Kraków 1995. Part 2. Prace Państwowego Instytutu Geologicznego 157.

Le Bayon, R., Brey, G.P., Ernst, W.G. \& Ferreiro Mählmann, R. 2011. Experimental kinetic study of organic matter maturation: Time and pressure effect on vitrinite reflectance at $400{ }^{\circ} \mathrm{C}$. Organic Geochemistry 42, 340-355. DOI 10.1016/j.orggeochem.2011.01.011

LIPIARSKI, I. 1976. Osady warstw žaclerskich (dolny westfal) w Niecce Słupca (Depresja Śródsudecka) oraz morfologia pokładów węgla. Prace Geologiczne Komisji Nauk Geologicznych PAN 101, 1-78.

Lopatin, N.V. 1971. Temperature and geologic time as factors in coalification. Izvestia Akademii Nauk SSSR Ser. Geol. 3, 95-106. [in Russian]

Lorenz, S. \& Mroczkowski, J. 1978. The sedimentation and petrography of Zechstein and lowermost Triassic deposits in 
the vicinity of Kochanów (Intra-Sudetic Trough). Geologica Sudetica 13, 23-39.

Łuszczak, K., Wyglądąa, M., Śmigielski, M., Waliczek, M., Matyja, B.A., Konon, A. \& Ludwiniak, M. 2020. How to deal with missing overburden - Investigating exhumation of the fragment of the Mid-Polish Anticlinorium by a multi-proxy approach. Marine and Petroleum Geology 114, art. 104229. DOI 10.1016/j.marpetgeo.2020.104229

Maluski, H., Rajlich, P. \& Souček, J. 1995. Pre-Variscan, Variscan and early Alpine thermo-tectonic history of the north-eastern Bohemian massif: an Ar/Ar study. Geologische Rundschau 84, 345-358. DOI 10.1007/s005310050010

Mastalerz, M. \& Jones, J.M. 1988. Coal rank variation in the Intra-Sudetic Basin, SW Poland. International Journal of Coal Geology 10, 79-97.

DOI 10.1016/0166-5162(88)90006-7

Mazur, S., Aleksandrowski, P., Kryza, R. \& Oberc-Dziedzic, T. 2006. The Variscan Orogen in Poland. Geological Quarterly 50, 89-118.

Mazur, S., Szczepański, J., Turniak, K. \& McNaughton, N.J. 2012. Location of the Rheic suture in the eastern Bohemian Massif: evidence from detrital zircon data. Terra Nova 24, 199-206. DOI 10.1111/j.1365-3121.2011.01053.x

McCann, T. (ed.) 2008. The Geology of Central Europe: Mesozoic and Cenozoic, vol. 2. 752 pp. The Geological Society, London. DOI 10.1144/CEV2P

Migoń, P. \& Lidmar-Bergström, K. 2001. Weathering mantles and their significance for geomorphological evolution of central and northern Europe since the Mesozoic. Earth Science Revue 56, 285-324. DOI 10.1016/S0012-8252(01)00068-X

Milewicz, J. 1997. Upper Cretaceous of the North Sudetic Depression (litho- and biostratigraphy, paleogeography, tectonics and remarks on raw materials). Prace GeologicznoMineralogiczne 61, 1-59.

Morrow, D.W. \& Issler, D.R. 1993. Calculation of vitrinite reflectance from thermal histories: A comparison of some methods. American Association of Petroleum Geologists Bulletin 44, 610-624.

MukHopadhyAy, P.K. 1992. Maturation of organic matter as revealed by microscopic methods: Applications and limitations of vitrinite reflectance, and continuous spectral and pulsed laser fluorescence spectroscopy, 435-510. In Wolf, K.H. \& Chilingarian, G.V. (eds) Diagenesis III. Developments in Sedimentology 47. DOI 10.1016/S0070-4571(08)70571-5

Nemec, W., Porębski, S. \& Teisseyre, A.K. 1982. Explanatory notes to the lithotectonic molasse profile of the Intra-Sudetic Basin, Polish part, Sudety Mts., Carboniferous-Permian. Veröffentlichungen des Zentralinstituts für Physik der Erde 66, 267-278.

Nielsen, S.B., Clausen, O.R. \& McGregor, E. 2017. Basin\%Ro: A vitrinite reflectance model derived from basin and laboratory data. Basin Research 29, 515-536. DOI $10.1111 /$ bre. 12160

NowAK, G.J. 1993. Lithotype variation and petrography of coal seams from Žaclér Formation (Westphalian) in the IntraSudetic Basin, SW Poland. Organic Geochemistry 20, 295-313. DOI 10.1016/0146-6380(93)90046-E
NowAK, G.J. 1996. Petrological coal seam accumulation model for the Žaclér Formation of the Lower Silesian Coal Basin, southwestern Poland, 261-286. In GAYer, R. \& HARris, I. (eds) Coalbed Methane and Coal Geology. Geological Society London, Special Publication 109.

DOI 10.1144/GSL.SP.1996.109.01.20

NowAK, G.J. 1997. Petrological variation of coals in the Intra-Sudetic Depression, southwestern Poland. Prace Państwowego Instytutu Geologicznego 157, 281-290.

NowAK, G.J. 2000. Thermal maturity of coals from the Lower Silesian Coal Basin on the background of their petrography and genesis. Biuletyn Państwowego Instytutu Geologicznego 391, 89-146.

Opluštil, S. \& CleAL, C.J. 2007. A comparative analysis of some Late Carboniferous basins of Variscan Europe. Geological Magazine 144, 417-448. DOI 10.1017/S0016756807003330

Opluštil, S., Schmitz, M., Kachlík, V. \& Š́tamberg, S. 2016. Re-assessment of lithostratigraphy, biostratigraphy, and volcanic activity of the Late Paleozoic Intra-Sudetic, Krkonoše-Piedmont and Mnichovo Hradiště basins (Czech Republic) based on new U-Pb CA-ID-TIMS ages. Bulletin of Geosciences 91, 399-432.

DOI 10.3140/bull.geosci.1603

PeŠEK, J. \& Sivek, M. 2016. Coal-bearing basins and coal deposits of the Czech Republic. 208 pp. Czech Geological Survey, Prague.

Pešek, J. \& SÝkorová, I. 2006. A review of the timing of coalification in the light of coal seam erosion, clastic dykes and coal clasts. International Journal of Coal Geology 66, 13-34. DOI 10.1016/j.coal.2005.05.010

Pepper, A.S. \& Corvi, P.J. 1995. Simple kinetic models of petroleum formation. Part I: oil and gas generation from kerogen. Marine and Petroleum Geology 12, 291-319. DOI 10.1016/0264-8172(95)98381-E

SAwicki, L. (ed.) 1995. Geological map of Lower Silesia with adjacent Czech and German territories (without Quaternary deposits) 1:100,000. Państwowy Instytut Geologiczny, Warszawa.

Scheck, M., Bayer, U., Otto, V., Lamarche, J., Banka, D. \& Pharaoh, T. 2002. The Elbe Fault System in North Central Europe - a basement controlled zone of crustal weakness. Tectonophysics 360, 281-299.

DOI 10.1016/S0040-1951(02)00357-8

Sechman, H., Kotarba, M.J., Dzieniewicz, M., Romanowski, T. \& Fiszer, J. 2017. Evidence of methane and carbon dioxide migration to the near surface zone in the area of the abandoned coal mines in Wałbrzych District (Lower Silesian Coal Basin, SW Poland) based on periodical changes of molecular and isotopic compositions. International Journal of Coal Geology 183, 138-160. DOI 10.1016/j.coal.2017.10.011

Sechman, H., Kotarba, M.J., Fiszer, J. \& Dzieniewicz, M. 2013. Distribution of methane and carbon dioxide concentrations in the near-surface zone and their genetic characterization at the abandoned "Nowa Ruda" coal mine (Lower Silesian Coal Basin, SW Poland). International Journal of Coal Geology 116-117, 1-16.

DOI 10.1016/j.coal.2013.05.005 
SkočEK, V. \& VAlečKa, J. 1983. Palaeogeography of the Late Cretaceous Quadersandstein of Central Europe. Palaeogeography, Paleoclimatology \& Paleoecology 44, 71-92. DOI 10.1016/0031-0182(83)90005-6

Sobczyk, A., Sobel, E.R. \& Georgieva, V. 2020. Meso-Cenozoic cooling and exhumation history of the Orlica-Śnieżnik Dome (Sudetes, NE Bohemian Massif, Central Europe): Insights from apatite fission-track thermochronometry. Terra Nova 32, 122-133. DOI 10.1111/ter.12449

Sobczyk, A., Danišík, M., Aleksandrowski, P. \& Anczkiewicz, A. 2015. Post-Variscan cooling history of the central Western Sudetes (NE Bohemian Massif, Poland) constrained by apatite fission-track and zircon (U-Th)/He thermochronology. Tectonophysics 649, 47-57.

DOI 10.1016/j.tecto.2015.02.021

Sobczyk, A., Durkowski, K., Botor, D. \& Sobel, E.R. 2018. Permo-Mesozoic to Cenozoic tectonothermal evolution of the North-Sudetic Synclinorium (Bohemian Massif, SW Poland), p.184. In Thermo 2018, Göttingen, Germany. Conference Book of Abstracts.

Suarez-Ruiz, I., Flores, D., Mendonca, J.G. \& Hackley, P.C. 2012. Review and update of the application of organic petrology: Part 1, geological applications. International Journal of Coal Geology 99, 54-112.

DOI 10.1016/j.coal.2012.02.004

Suchý, V., Frey, M. \& Wolf, M. 1997. Vitrinite reflectance and shear-induced graphitization in orogenic belts: A case study from the Kandersteg area, Helvetic Alps, Switzerland. International Journal of Coal Geology 34, 1-20. DOI 10.1016/S0166-5162(97)00018-9

Suchý, V., Filip, J., SÝkorová, I., Pešek, J. \& Kořínková, D. 2019. Palaeo-thermal and coalification history of PermoCarboniferous sedimentary basins of Central and Western Bohemia, Czech Republic: first insights from apatite fission track analysis and vitrinite reflectance modelling. Bulletin of Geosciences 94, 201-219. DOI 10.3140/bull.geosci.1696

SweEney, J.J. \& BuRnhAM, A.K. 1990. Evaluation of a simple model of vitrinite reflectance based on chemical kinetics. American Association of Petroleum Geologists Bulletin 74, 1559-1570. DOI 10.1306/0C9B251F-1710-11D7-8645000102C1865D

TeichmülleR, M. 1987. Organic material and very low-grade metamorphism, 114-161. In FREY, M. (ed.) Low Temperature Metamorphism. Blackie, Glasgow.

Teichmüller, R. \& Teichmüller, M. 1986. Relations between coalification and paleogeothermics in Variscan and Alpidic foredeeps of Western Europe, 53-78. In BunteBARTH, G. \& Stegena, L. (eds) Paleogeothermics. Lecture notes in Earth Sciences 5. Springer-Verlag, New York. DOI 10.1007/BFb0012102

Teisseyre, A.K. 1968. The Lower Carboniferous of the IntraSudetic Basin: sedimentary petrology and basin analysis. Geologica Sudetica 4, 221-298.

TeisSEYRE, A.K. 1975. Sedimentology and paleogeography of the Culm alluvial fans in the Intra-Sudetic Basin (Sudetes, SW Poland). Geologica Sudetica 9, 7-135.

Thomson, S.N. \& Zen, A. 2000. Fission-track thermochronology of the Ruhla Crystalline Complex: new constraints on the
post-Variscan thermal evolution of the NW Saxo-Bohemian Massif. Tectonophysics 324, 17-35.

DOI 10.1016/S0040-1951(00)00113-X

Turnau, E., Żelaźniewicz, A. \& Franke, W. 2005. Middle to early late Viséan onset of late orogenic sedimentation in the Intra-Sudetic Basin, West Sudetes: miospore evidence and tectonic implication. Geologia Sudetica 34, 9-16.

Uglik, M. \& Nowak, G.J. 2015. Petrological recognition of bituminous inertinite enriched coals of the Lower Silesian Coal Basin (Central Sudetes, SW Poland). International Journal of Coal Geology 139, 49-62.

DOI 10.1016/j.coal.2014.07.009

UličnÝ, D., ŠpičÁkovÁ, L., Grygar, R., Svobodová, M., Čech, S. \& Laurin, J. 2009. Palaeodrainage systems at the basal unconformity of the Bohemian Cretaceous Basin: Roles of inherited fault systems and basement lithology during the onset of basin filling. Bulletin of Geosciences 84, 577-610. DOI 10.3140/bull.geosci.1128

Ulrych, J., Fediuk, F., Lang, M. \& Martinec, P. 2004. Late Paleozoic volcanic rocks of the Intra-Sudetic Basin, Bohemian Massif: petrological and geochemical characteristics. Chemie der Erde-Geochemistry 64, 127-153.

DOI 10.1016/j.chemer.2003.11.002

Vamvaka, A., Siebel, W., Chen, F. \& Rohrmuller, J. 2014. Apatite fission-track dating and low-temperature history of the Bavarian Forest (southern Bohemian Massif). International Journal of Earth Sciences 103, 103-119.

DOI 10.1007/s00531-013-0945-x

VenturA, B. \& Lisker, F. 2003. Long-term landscape evolution of the NE margin of the Bohemian Massif: apatite fission-track data from the Erzgebirge (Germany). International Journal of Earth Sciences 92, 691-700.

DOI 10.1007/s00531-003-0344-9

Ventura, B., Lisker, F. \& Kopp, J. 2009. Thermal and denudation history of the Lusatian Block (NE Bohemian Massif, Germany) as indicated by apatite fission-track data, 181-192. In Lisker, F., Ventura, B. \& Glasmacher, U.A. (eds) Thermochronological methods: from Palaeotemperature constraints to landscape evolution models. Geological Society London, Special Publications 324. DOI 10.1144/SP324.14

WAGner, M. 2013. The geological aspects of meta-lignite and sub-bituminous coal occurrences in Poland within the context of deposits and uneconomic occurrences in Europe. Gospodarka Surowcami Mineralnymi - Mineral Resources Management 29, 25-45. DOI 10.2478/gospo-2013-0046

Waples, D.W. 1980. Time and temperature in petroleum formation: application of Lopatin's method to petroleum exploration. American Association of Petroleum Geologists Bulletin 64, 916-926.

DOI 10.1306/2F9193D2-16CE-11D7-8645000102C1865D

Waples, D., Kamata, H. \& Suizu, M. 1992a. The art of maturity modeling, part 1: finding of a satisfactory model. American Association of Petroleum Geologists Bulletin 76, 31-46. DOI 10.1306/BDFF875E-1718-11D7-8645000102C1865D

Waples, D., Kamata, H. \& Suizu, M. 1992b. The art of maturity modeling, part 2: alternative models and sensitivity analysis. 
American Association of Petroleum Geologists Bulletin 76, 47-66.

DOI 10.1306/BDFF8768-1718-11D7-8645000102C1865D

WoJewOdA, J. 1997. Upper Cretaceous littoral-to-shelf succession in theIntra-SudeticBasinandNysa Trough, Sudetes Mts., 81-96. In WoJewodA, J. (ed.) Obszary źródłowe: zapis w osadach. WIND, Wrocław.

Wolff, R., Dunkl, I., Lange, J.-M., Tonk, C., Voigt, T. \& Eynat-
TEN, H. VON 2015. Superposition of burial and hydrothermal events: post-Variscan thermal evolution of the Erzgebirge, Germany. Terra Nova 27, 292-299.

DOI 10.1111/ter.12159

Ziegler, P.A. \& Dèzes, P. 2007. Cenozoic uplift of Variscan Massifs in the Alpine foreland: Timing and controlling mechanisms. Global \& Planetary Change 58, 237-269.

DOI 10.1016/j.gloplacha.2006.12.004 